\title{
Doing more with less: The Marie Stopes Clinics in Sierra Leone
}

Nahid Toubia

Grace Ebun Delano

Follow this and additional works at: https://knowledgecommons.popcouncil.org/departments_sbsr-pgy

Part of the Family, Life Course, and Society Commons, Gender and Sexuality Commons, Health Policy Commons, International Public Health Commons, Maternal and Child Health Commons, Public Health Education and Promotion Commons, and the Women's Health Commons How does access to this work benefit you? Let us know!

\section{Recommended Citation}

Toubia, Nahid and Grace Ebun Delano. 1995. "Doing more with less: The Marie Stopes Clinics in Sierra Leone," Quality/Calidad/Qualité no. 7. New York: Population Council. 
Doing More with Lesšst

The Marie Stopes Glinies in Sierra Leone

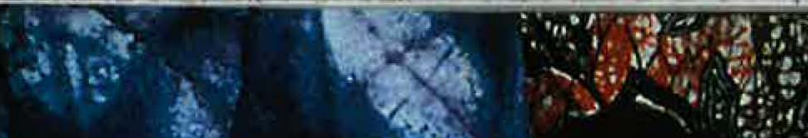
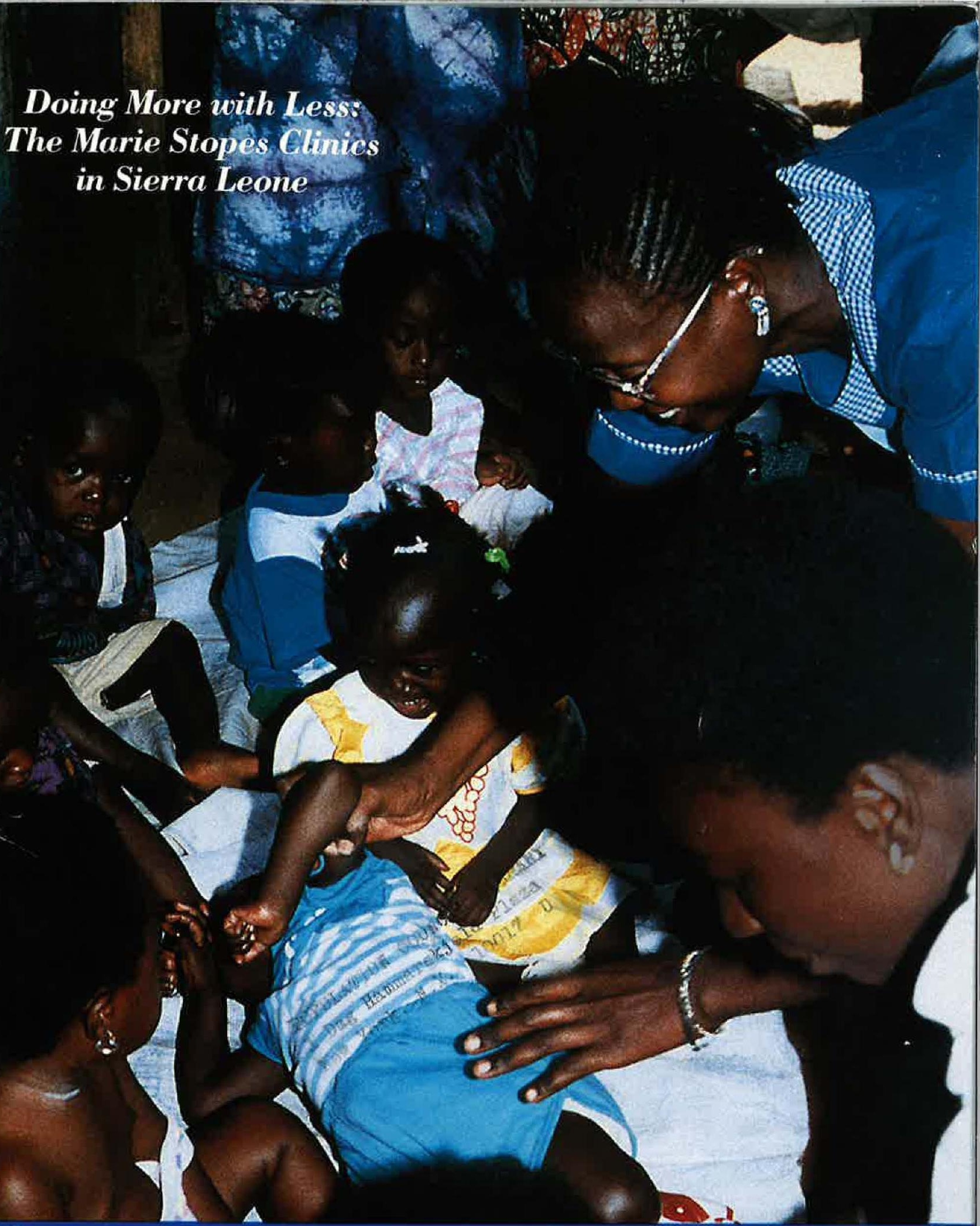
IOmality / Calidad / Qualité / Qu

"в

86

.8933

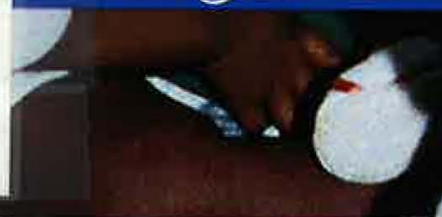

$x^{2}=7$ 
Quality/Calidad/Qualité, a publication of the Population Council, highlights examples of family planning and reproductive health programs that are providing unusually high quality care. This series is part of the Council's Robert H. Ebert Program on Critical Issues in Reproductive Health and Population which, through scientific and practical efforts, seeks to improve and expand the scope and quality of reproductive health care. The philosophical foundation of the program, and of this series, is that women and their partners have a fundamental right to respectful treatment, information, choice and follow-up from reproductive health care providers. The pamphlets reflect one of the four main thrusts of the program: enhancing the quality of family planning programs.

Projects are selected for documentation in the Quality/Calidad/Qualité series by an Advisory Committee made up of individuals who have a broad range of experience within the field of reproductive health and are committed to improving the quality of services. These projects are making important strides in one or more of the following ways: broadening the choice of contraceptive methods and technologies available; providing the information clients need to make informed choices and better manage their own health care; strengthening the quality of client/provider interaction and encouraging continued contact between providers and clients; making innovative efforts to increase the management capacity and broaden the skills of service providers at all levels; expanding the constellation of services and information provided beyond those conventionally defined as "family planning;" and reaching underserved and disadvantaged groups with reproductive health care services.

None of the projects documented in the series is being offered as a model for replication. Rather, each is presented as an unusually creative example of values, objectives and implementation. These are "learning experiences" that demonstrate the self-critical attitude required to anticipate clients' needs and find affordable means to meet them. This reflective posture is exemplified by a willingness to respond to changes in clients' needs as well as to the broader social and economic transformations affecting societies. Documenting the critical choices these programs have made should help to reinforce, in practical terms, the belief that an individual's satisfaction with reproductive health care services is strongly related to the achievement of broader health and population goals.

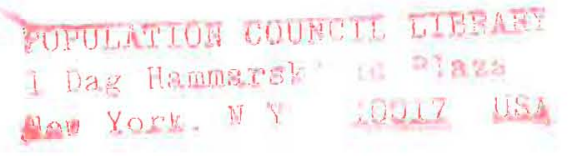

Publication of this edition of Quality/ Calidad/Qualité is made possible by support provided by the Ford Foundation and the Swedish International Development Authority (SIDA).
Statements made and views expressed in this publication are solely the responsibility of the authors and not of any organization providing support for Quality/ Calidad/Qualité. 


\title{
Doing More with Less: The Marie Stopes Clinics in Sierra Leone
}

\author{
by Nahid Toubia \\ Introduction by Grace Eban Delano
}

\section{Introduction}

In Africa, high fertility is known to be a major contributor to maternal mortality and morbidity. Studies have shown that of every ten deaths to women of reproductive age, at least six are caused by factors relating to pregnancy, child birth and related complications in the postpartum period, most of which are fully avoidable. It has also been widely documented that when a woman becomes pregnant too young, too soon (following a previous birth), or too old, she is likely to suffer health problems with grievous complications.

The benefit of voluntary, health-oriented family planning programs in preventing the death and illness of women and children cannot be over-emphasized. When a woman is able to have the number of children she can adequately care for, at safe intervals, she is more likely to remain healthy and to be able to pursue daily activities which contribute to her own and her family's welfare. And because women play a major role in most agrarian economies of Sub-Saharan Africa-tilling, planting and harvesting crops as well as caring for and supporting families and children - they not only have a right to health but their well-being also has vital implications for economic development.

The consequences of a combination of high fertility, mortality and morbidity among poor women can also lead to a range of other problems.

- Complications of childbirth can lead to long-term disabilities, general poor health and even death for many women.

- Attempts at unsafe and illegal abortion, often accompanied by complications, impair women's health and sense of security.

- Early childbearing interferes with the educational attainment of young girls who must drop out of school, resulting in a lifetime of limited reproductive and productive choices.

- The death of a mother through childbirth or unsafe abortion, or her inability to care for her children due to ill health, can result in greater numbers of orphaned, abandoned or abused children.

\section{The Role of Non-Governmental Organizations (NGOs) in Health and Development}

In the period following independence, the provision of health care, in the African context, was viewed primarily as the precinct of governments. But in recent years, political instability and economic mismanagement, coupled with universal economic recession, has forced many African governments to institute so called economic structural adjustment programs (SAP) to reduce their external debt. Although the ultimate goal of these efforts is to improve the economy and thus create better living conditions for everyone, the implementation of these policies has actually led, in the near term, to a deepening socio-political crisis within African nations. This has had particularly deleterious effects on women and children because one usual component of such programs is reduced government spending on health and other social services. Already overburdened and often under-developed, health care systems then either collapse altogether or are forced to limit care to those who can afford service fees. Services that were once available free of charge now cost money if, in fact, the services are even available. 
Budget reductions can also mean that medical personnel are frequently unpaid, sometimes for months at a time, resulting in frequent strike actions which then create increasing distrust among health providers and, ultimately, further chaos within the public health sector. And despite the austerity rhetoric of SAP, official corruption continues to flourish, further impoverishing people who are politically powerless, illiterate, and poor-people who have no understanding of the long-term, macro level economic problems SAP is meant to address.

In Africa NGOs have a long history of providing health care, especially family planning services. Therefore, it is not surprising that given the unpredictability of governments' response to meeting people's health needs, many NGOs have intensified their efforts in an attempt to fill the void.

NGOs have generally approached the provision of family planning as an integral part of reproductive health care programs associated with primary health care. Such programs:

- Provide an opportunity for child spacing and fertility choices.

- Prevent unwanted pregnancies and provide an environment that is supportive of women's reproductive health needs.

- Provide services that ensure a woman's access to quality medical care during pregnancy, childbirth and the postpartum period, (i.e. safe motherhood).

- Inform, educate and counsel the larger community on socio-cultural barriers that contribute to unsound reproductive health practices and the effects of such practices on mothers, children, families, and society.

\section{Advantages of NGOs}

Because they are generally smaller in size and enjoy more flexible management structures, many NGOs have been able to institute and sustain innovative approaches to meeting clients' reproductive health goals despite the waxing and waning fortunes of government services.

1. Lack of Bureaucracy. NGOs tend to have fewer levels of management and less rigid regulations - that is, less red tape. Timeliness and the personal touch in the implementation of programs tend to lead to greater trust between provider and client as well as, in most cases, greater overall effectiveness and efficiency.

2. Innovativeness. The size, structure and nature of NGOs put them in a better position to more rapidly test alternative approaches to service delivery and then to adopt those innovations that have proved successful.

3. Accountability. While most NGOs operate out of a deep social consciousness, nevertheless they must manage within limited budgets and are accountable for the quality of care they render. Therefore, they tend to pursue service delivery in a business-like manner which is at the same time client-centered and result-oriented.

4. Maximizing Scarce Resources. Most NGOs, despite some degree of competition, are willing to work together. In the best cases, the diverse expertise of a number of organizations can thus be combined to provide clients with a system of referral and support.

5. Challenging Convention. With aware and committed leadership, NGOs are often able to advocate change and challenge many cultural and even legal barriers that hinder the spread of reproductive health information and services. Thus they are able to open doors where larger, government programs can subsequently follow.

The operations of NGOs, however, are not free from problems. Because in Africa local resources are often limited, their funding must come from international (private and governmental) donor agencies. This leaves them susceptible to country-to-country vagaries. Support may also be predicated upon the political situation in the receiving country and thus may be vulnerable to a changing political climate or civil turmoil. Uncertain political environments in many African nations can lead to frequent delays in receipt of funds or commodities which, in turn, can have a significant negative effect on the delivery of services.

Even through they usually charge something for services, NGOs still must wrestle with how to balance client affordability with self-sufficiency. Because most of their clients are poor, the 
amount NGOs can recover from client fees is usually insufficient to sustain their programs. And because the programs of most NGOs are relatively small, they frequently have to limit their coverage to poor, densely populated peri-urban communities while in sub-Saharan Africa, most of the unmet need is in dispersed rural areas which are far more difficult to serve.

\section{The Essential Message}

The success story of the Marie Stopes Society of Sierra Leone (MSSL) is particularly striking in the face of the economic and political turmoil that has faced Sierra Leone. It is just short of amazing that MSSL has not only been able to continue providing quality care, but has also been able to continually expand its services. MSSL's experience demonstrates how the flexibility of an NGO can result in the provision of a constellation of services within the same environment that make it easy for clients to meet their diverse needs in the same place and at the same time.

Primary credit goes to MSSL's remarkable staff and to the flexibility and steadfastness of their primary funder and technical resource, Marie Stopes International in the United Kingdom. However, to be able to surmount the obstacles in its path, MSSL has been able to establish positive relationships with a variety of local agencies, public and private, that have enabled the organization to reach a diverse clientele in a variety of service settings. And, of vital importance, MSSL has established a strong base of support within the community.

For NGOs in sub-Saharan Africa to continue bridging the gap between the demand for reproductive health care and scarce resources, they will continue to need, as an adjunct to strong local initiative and sheer hard work, committed and flexible support from national and international donor agencies. Both are essential if reproductive health goals are to be attained.

Grace Delano would like to express her thanks to Ms. Christy Laniyan, Association for Reproductive \& Family Health's Program Development Coordinator for her contribution to this Introduction.

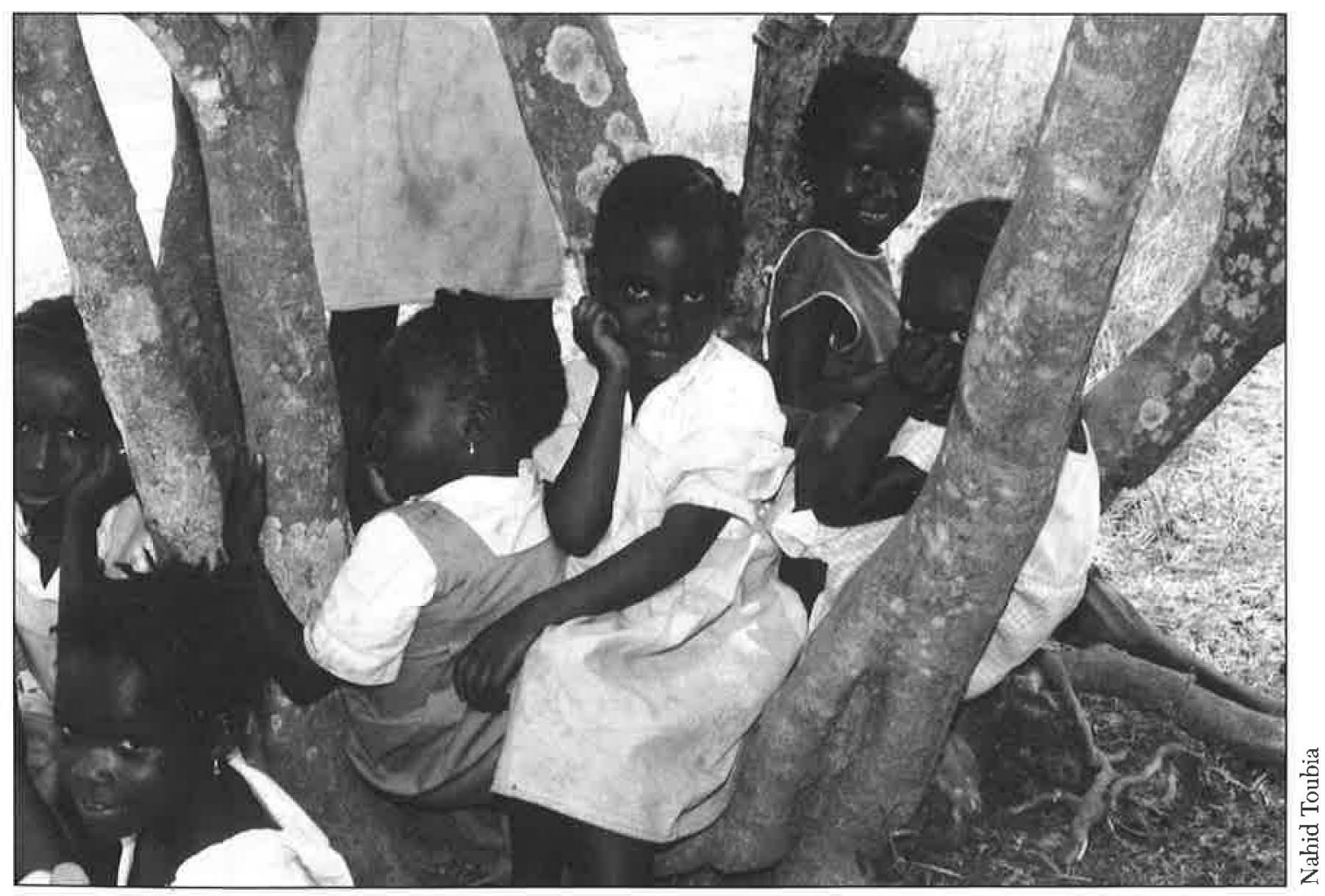




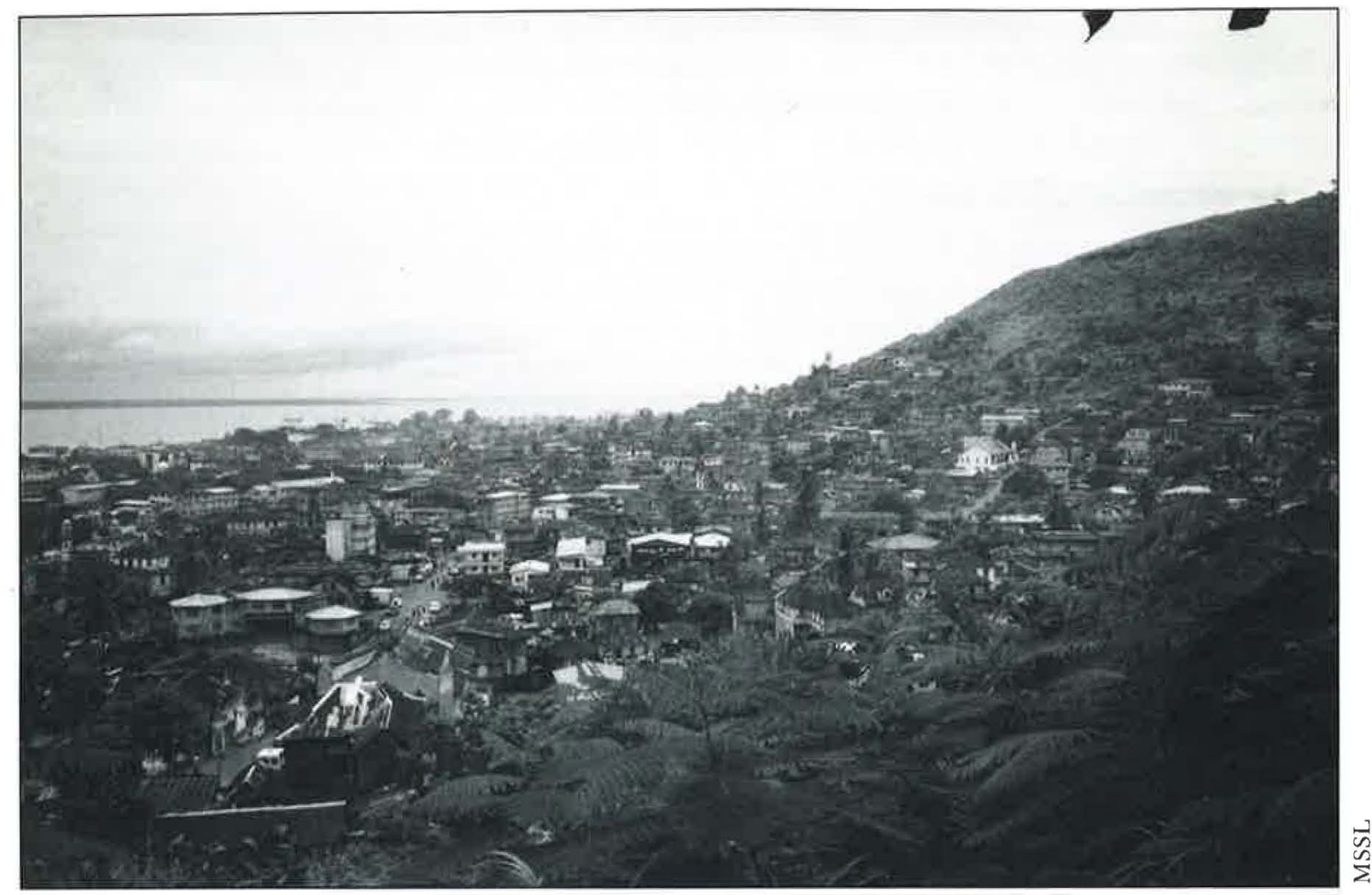

\section{Background}

Located on the west coast of Africa, between Guinea and Liberia, Sierra Leone ("lion mountain") is the home to some 18 ethnic groups, as well as the descendants of freed slaves from the British Empire and North America. Known locally as Creoles, the former slaves settled in Sierra Leone, then a British colony, in the late eighteenth and early nineteenth centuries. The nation's capital, Freetown, gained its name as the site where these Africans returned from exile. The majority, cut off from their own lands and traditions by the experience of slavery, chose to remain in Sierra Leone.

Sierra Leone is a country rich in natural resources. With a wide coastal front on the Atlantic Ocean and lush inland of hills and plains covered by rain forests and savannah, Sierra Leone has the potential to feed itself. Before the outbreak of civil strife in 1991, mining of diamonds, rutile and other minerals was the primary source of the country's foreign exchange. However, Sierra Leoneans watched their economy go from bad to worse in recent years, as mineral prices dropped and the cost of imports such as oil rapidly escalated. This eco- nomic decline, coupled with rampant corruption, government instability and the spillover of political turmoil from neighboring Liberia, has left the country in a precarious condition. In 1992 the military ousted the long-standing government of 24 years in a bloodless coup d'etat. Now under military rule, Sierra Leone is in a period of "revolution" in an attempt to turn things around.

Today, Sierra Leone's economy is in a desperate state, suffering from rampant inflation and corruption. By 1993, per capita annual income was just U.S. $\$ 240$; the economy has registered zero growth in the gross domestic product since 1980 . Today petty trading and subsistence farming are the most common means of support for most Sierra Leoneans. The meager salaries of government workers and other professionals have forced many to either abandon their professions or take up some form of trading to make ends meet. As a result, the public sector can no longer provide anything but minimal services. The situation has been further exacerbated since many international development programs withdrew from Sierra Leone in recent years due to high levels of political and economic instability. 


\section{Women's Reproductive Health}

Sierra Leone's calamitous economic situation has serious repercussions for women's reproductive health. Although the 1985 census reported a literacy rate for adult females of 21 percent, current observations suggest that this is an overestimate and that the situation is worsening, as the educational system has been steadily collapsing. For the majority of uneducated women, learning about what it means to be a woman comes during their initiation ceremony into the traditional secret societies common in Sierra Leone. These initiation trainings and rituals take from two weeks to three months and occur under the supervision of an elderly woman who takes the young girls away from their families. The content of this training is a mixture of useful knowledge and the harmful practice of circumcision.

Since agricultural production in Sierra Leone does not meet the food requirements of its population, the lives of mothers and children are constantly threatened by inadequate nutrition, as well as poor living conditions and insufficient medical care. Both child and maternal mortality rates in Sierra Leone are among the highest in the world: 150-200 per 1000 and 2,500 per 100,000 , respectively. The average woman bears six to seven children during her lifetime and complications of pregnancy and childbirth are a major cause of death among women. The high incidence of maternal mortality is compounded by rapidly growing numbers of teenage pregnancies, with the attendant problems of birth complications, unsafe abortions, abandoned babies and disrupted schooling.

This situation is further exacerbated by very low literacy rates, the effects of boredom caused by unemployment and limited access to family planning. Many areas are without any medical or family planning care whatsoever and less than 3 percent of the country's 750,000 women of childbearing age use effective contraception. Most people rely on traditional methods, which are at best uncertain, and at worst dangerous. The need for low-cost, effective maternal and child health and family planning services is, therefore, overwhelming.

\section{Family Planning in Sierra Leone}

Prior to the establishment of a National Population Policy in 1988; Sierra Leone had very few family planning services. Around the time the policy was being developed, 14 nongovernmental organizations (NGOs) were providing some family planning services. However, given the service and management difficulties unique to Sierra Leone, few have survived.

UNICEF is now executing the National Family Planing/Maternal Child Health (MCH) Project, funded by United Nations Population Fund (UNFPA). This program operates through government health centers and posts and also assists NGOs like Marie Stopes Sierra Leone (MSSL) and the Planned Parenthood Association of Sierra Leone (PPASL). Both MSSL and PPASL receive some assistance, including contraceptive supplies, from this project.

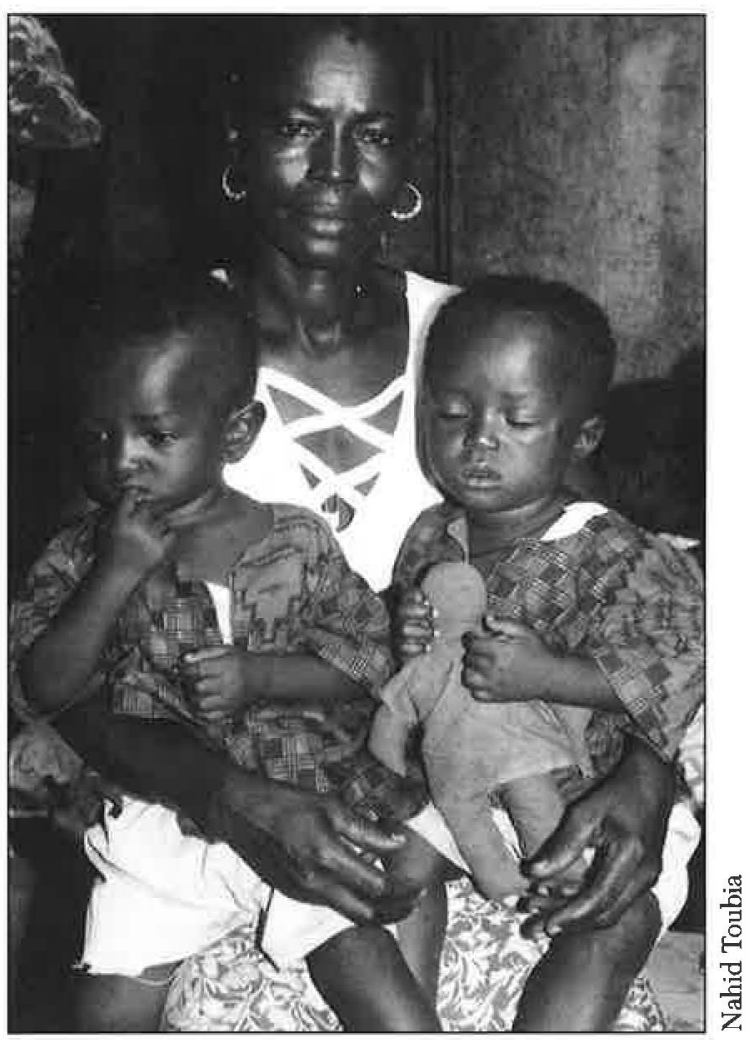




\section{Marie Stopes International (MSI)}

Marie Stopes International is a registered charity in the United Kingdom (UK) that works in both the developed and developing world to help men and women plan their families and avoid unwanted pregnancies. The organization was named for Dr. Marie Stopes (1880-1958), the founder of Britain's first birth control clinic. Dr. Stopes, a paleobotanist, fervently advocated contraceptive choice and the elimination of the fear of unwanted pregnancy.

In the UK, MSI runs a successful network of clinics for women's reproductive health and vasectomy and provides services on a fee-paying basis to nearly 50,000 men and women annually. Income generated by these programs helps to defray some of the administrative costs of MSI's overseas activities. Marie Stopes International provides technical and financial assistance to a wide range of innovative and low-cost service delivery, social marketing and educational projects in the maternal and child health and family planning fields in developing countries which operate either through existing NGOs or MSI helps concerned local individuals establish an organization specifically geared to provide family planning. The goal is to assist those individuals and families most vulnerable to the hazards of unwanted pregnancy, unsupervised pregnancies and deliveries, sexually transmitted diseases (STDs), and other reproductive health problems.

Marie Stopes International itself receives funding from the British Government's Overseas Development Administration, the European Economic Community (EEC), voluntary trusts and foundations, businesses and individual donors. Projects are funded by grants for a predetermined period (usually three years), and service delivery programs operate on a cost-recovery basis with the aim of achieving self-sufficiency.

\section{A Total Health Care Approach to Family Planning}

Family planning is not easy. You have to be patient and learn what people want, instead of dragging them along. Education is about understanding people and getting them to take the initiative and responsibility, so that even when you are not there they will get what they want somewhere else.

\section{Sylvia Wachuku King}

This statement, by the director of the Marie Stopes Society of Sierra Leone (MSSL), summarizes the operational philosophy of this group of clinics. From the beginning, MSSL's emphasis has been on women's health, including reduction of reproductive mortality and morbidity, assisting women in child spacing and fertility choices and preventing problems associated with unwanted pregnancy. To attain such a goal is indeed a challenge in a country where the economic and service infrastructure is collapsing.

To serve as many people as possible, MSSL has adopted an integrated approach to reproductive health care that includes family planning, treatment of sexually transmitted dis- eases, prenatal care and simple gynecological surgical procedures. General health services, especially for children under age five, are also available. A compelling reason for providing such a broad range of services is that medical care in Sierra Leone has become very expensive, beyond the reach of middle and lowincome people: The average income of a school teacher, for example, has averaged about US $\$ 10$ a month, or U.S. $\$ 120$ per year, since the early 1990s. Therefore it seems inappropriate to MSSL to provide only reproductive health care to clients and then abandon them when they are suffering from malaria or other endemic diseases. Further, by providing more than just family planning or even comprehensive reproductive health care, MSSL has been able to gain clients' satisfaction and confidence.

On March 1, 1988, the first Marie Stopes Sierra Leone Clinic opened on Collegiate School Road in Freetown. Demand for services increased steadily during the first year of operation and, by the end of 1988 , the clinic register showed that 2,424 clients (men, women and children) had come for 10,046 consultationsan average of four to five visits by each client per year. Women who visit the clinic are primarily low-income petty traders, mostly in their 
mid to late twenties. As the majority of clients are illiterate and unable to report their ages accurately, MSSL staff have devised an effective method to estimate their ages so they can maintain reliable client records.

As the number of clients increased, more staff was recruited and services added. A nutrition clinic for under-fives was established and later extended to include malnourished pregnant women. MSSL is also a center for the Extended Program of Immunization, which provides free immunization to mothers and children.

MSSL gradually introduced laboratory tests into its service and the clinic now takes Pap smears for cervical cancer and high vaginal swabs to test for sexually transmitted diseases. These are sent to outside laboratory facilities for analysis. Routine testing for pregnancy, urine tests for sugar and protein and blood hemoglobin samples are performed on the premises. Initially only female clients came for treatment of sexually transmitted diseases; they were given an extra supply of drugs for their male partners. However, because the clinic's open-door policy does not exclude men, infected male partners started coming and have gradually begun to feel more comfortable using
MARIE STOPES SOCIETY SIERRA LEONE SUMMARY CLINIC DATA January-December 1994

OTHER REPRODUCTIVE HEALTH CARE TOTAL

Gynecological Consultations 9,254

Sexually Transmitted Diseases $\quad 2,100$

Antenatal Care

4,874

Postnatal Care

169

Deliveries

238

Other Operations

TOTAL OTHER REP HEALTH

Children Under Five Medical

16,653

Adult Medical 8,163

GRAND TOTAL CLIENTS

9,135

Pregnancy Tests

56,378

Laboratory Tests

2,436

New Family Planning Acceptors

6,851

TOTAL CONSULTATIONS

5,786

61,634

the clinic. A few bold clients occasionally volunteer to take an HIV test; however, the clinic does not advise clients whether or not to be tested for HIV and does not routinely perform the procedure.

Next a dispensary/accounts section was added to the reception area. Here clients purchase contraceptive supplies and medicines and pay their fees. Clients come from all parts

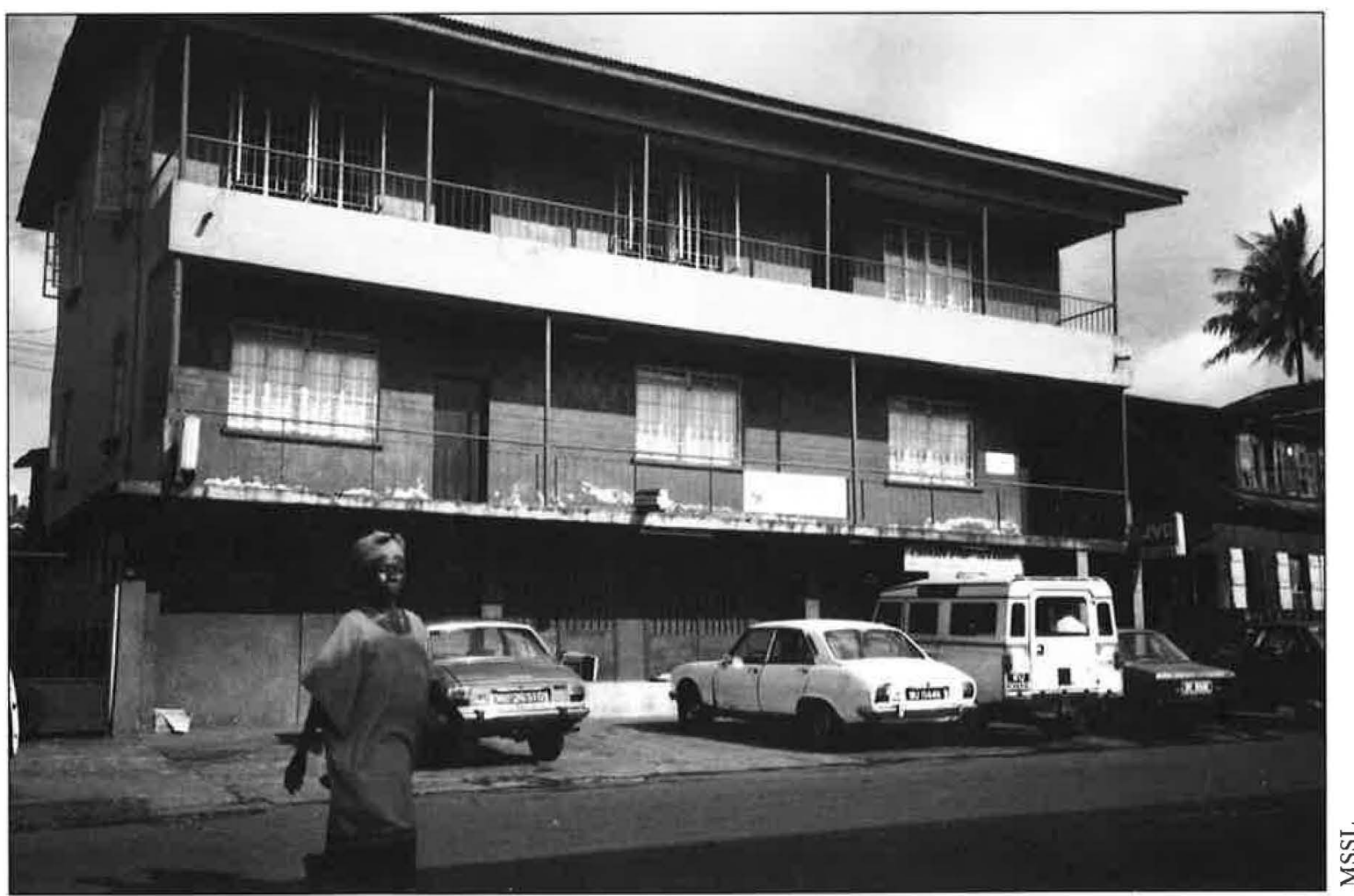




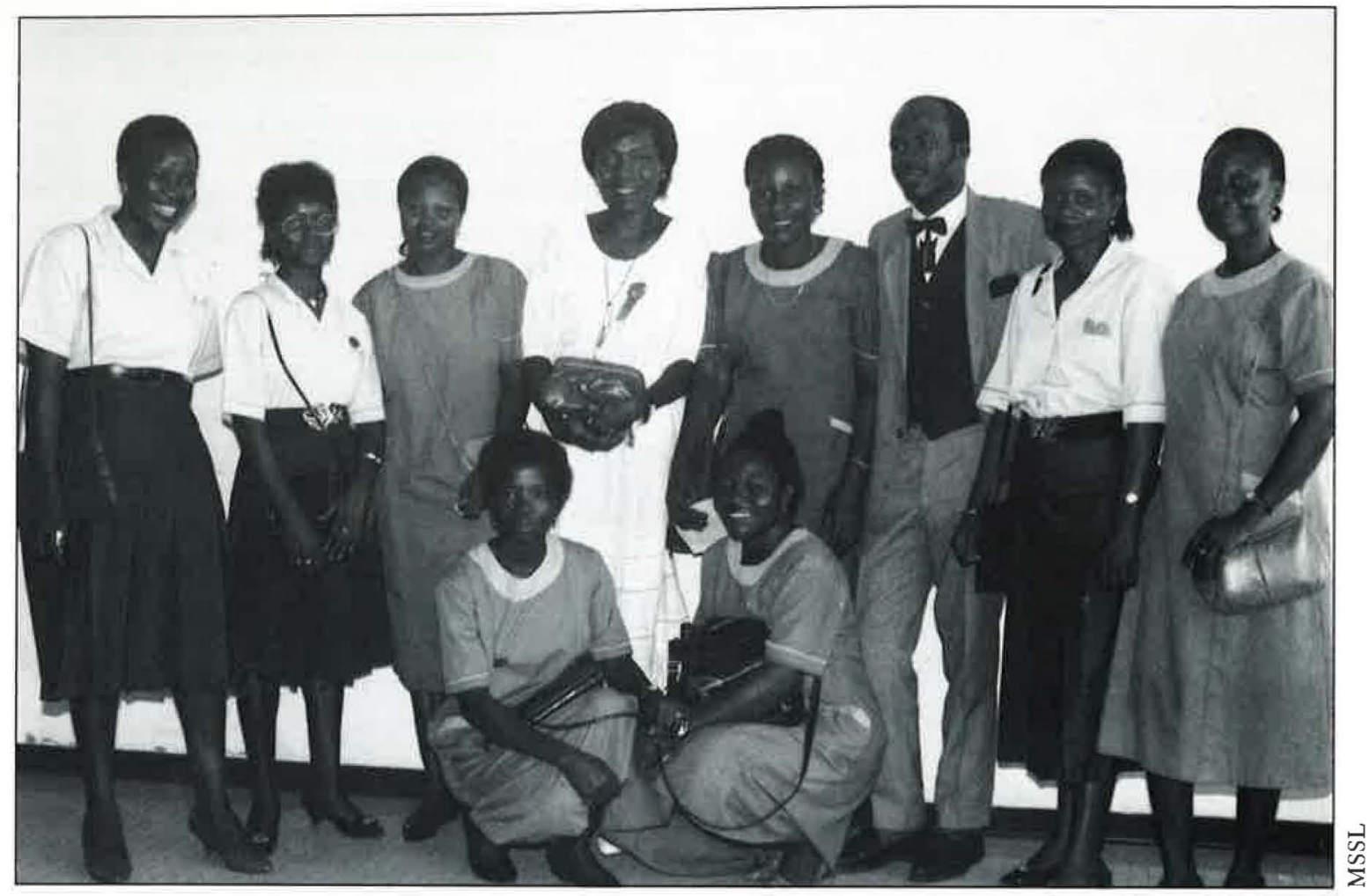

of Freetown, despite high transportation costs, because MSSL charges fees that are within a range most Sierra Leoneans can afford. If a client is unable to pay, fees can be waived but fortunately such occasions do not often occur.

By mid-1989, MSSL had leased a building in a centrally located area of the city to house the Society's headquarters and a small clinic. By the end of 1991, the main clinic in Freetown had to be moved to a larger site to accommodate the rising number of clients. In mid-1992, MSSL realized a goal it had held since 1988 - to offer good quality obstetric services to low-income women living far from a hospital. An obstetric unit was established at 14a Aberdeen Ferry Road which serves as a Safe Motherhood Center. It offers a full range of prenatal, maternity and postnatal services and the ten-bed unit is open for deliveries 24 hours a day. Clients are provided with three meals daily during their stay. By October 1993, a laboratory and an operating theater had been opened so that Caesarian sections and treatment of other obstetric complications can now be performed on site. Blood needed for operations is obtained from the Red Cross or the government hospital.

\section{The Staff}

The first clinic started with eight full-time and three part-time staff, including medical consultants. By the end of the first three years, there were twelve full-time and five part-time staff. In recent years, staff turnover has lessened-down to only about 5 percent since 1992-3 because fewer people are now leaving the country. Currently MSSL employs 89 fulltime and three part-time staff, including nonmedical personnel.

Most staff training is undertaken in-house and includes not only training and assessment of technical competence but also an orientation to the goals and ethics of MSSL. This orientation is considered an important component in ensuring continued high levels of client care and in promoting staff harmony. At MSSL, child clinics, prenatal care and family planning (with the exception of sterilization) are provided by nurses, as are simple STD diagnosis and treatment. Physicians diagnose and treat general medical problems and are called upon for advice in difficult maternal and child health cases. MSSL currently is receiving assistance from the United Nations Population Fund (UNFPA) for staff training both locally and abroad. 


\section{Maintaining a Commitment to High Quality Care: Challenges and Rewards}

In a hot and humid climate with temperatures of $90-102^{\circ} \mathrm{F}$, managing to keep morale high, while maintaining the dignity and selfrespect of both staff and clients is a real challenge. Raising people's interest in preventive health measures such as family planning is not easy when they can barely secure sufficient food and must constantly fight acute illnesses. Yet Marie Stopes Sierra Leone has risen to the challenge and arrived at some, if not all of the answers. Each day new solutions must be found to endlessly vexing problems.

The precarious balance between obtaining the supplies necessary to run the clinics and attending to the demands of each service has to be addressed on a month-to-month, and sometimes day-to-day, basis. Keeping an adequate stock of supplies is in itself a formidable task, extending beyond contraceptives and drugs to antiseptics, soap, office supplies, and imported goods. In the early years, MSSL also faced frequent shortages of gasoline and replacement parts for equipment. However, this situation has recently improved.

For clients to have confidence in the clinic's program, they need to know that they will always be able to obtain the contraceptive of their choice or the drug prescribed for them, and that they will be provided with clean sheets and towels during their visit. Inconsistencies in any of these areas can result in a loss of faith in the clinic. Thus the staff responsible for procurement are trained to be resourceful in the face of an unstable market. MSSL stresses that having adequate supplies is vital to sustaining the quality of its services.

For some time, just maintaining communications with the outside world, particularly during emergencies or periods of acute shortages, posed a real problem. Telephones were constantly out of order and frequently there was no electricity. However, throughout these hard times, MSSL managed, to the best of its ability, to maintain its high standards.

In the early years, MSSL faced other unforeseeable difficulties on an almost routine basis. For example, in late 1989 there was a constant shortage of water in Freetown. Since keeping clinics clean is impossible without water, each of MSSL's main clinics was fitted with a large tank to hold a supply of water for use when it was not available from the tap. Despite such precautions, the following situation was not uncommon.

It is 2:00 p.m. on a Wednesday. There has been a water shortage since Monday, exhausting the supply in the tank. The afternoon session in the operating theater is scheduled to begin, and the doctor and the women are waiting. Buckets and plastic gallon containers are brought from the storeroom. Staff members then go around town by car until they have secured sufficient water so that the clients awaiting surgery need not be turned awaysomething MSSL tries to avoid at all costs. In addition, the clinic will need to be washed down in preparation for reopening at 8:30 a.m. the next day. In such a crisis the entire staff helps out, and usually the situation is successfully resolved. However, if all efforts fail and water cannot be secured, every possible compensation is made to the clients (such as payment of transportation fees) and their procedures are rescheduled.

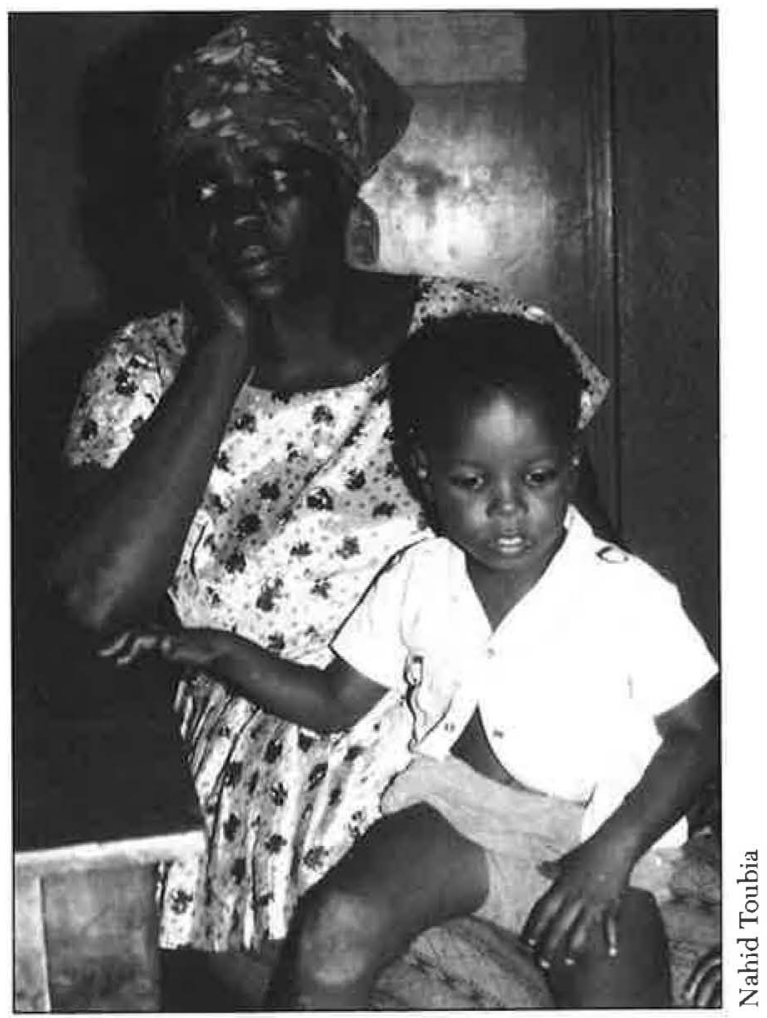




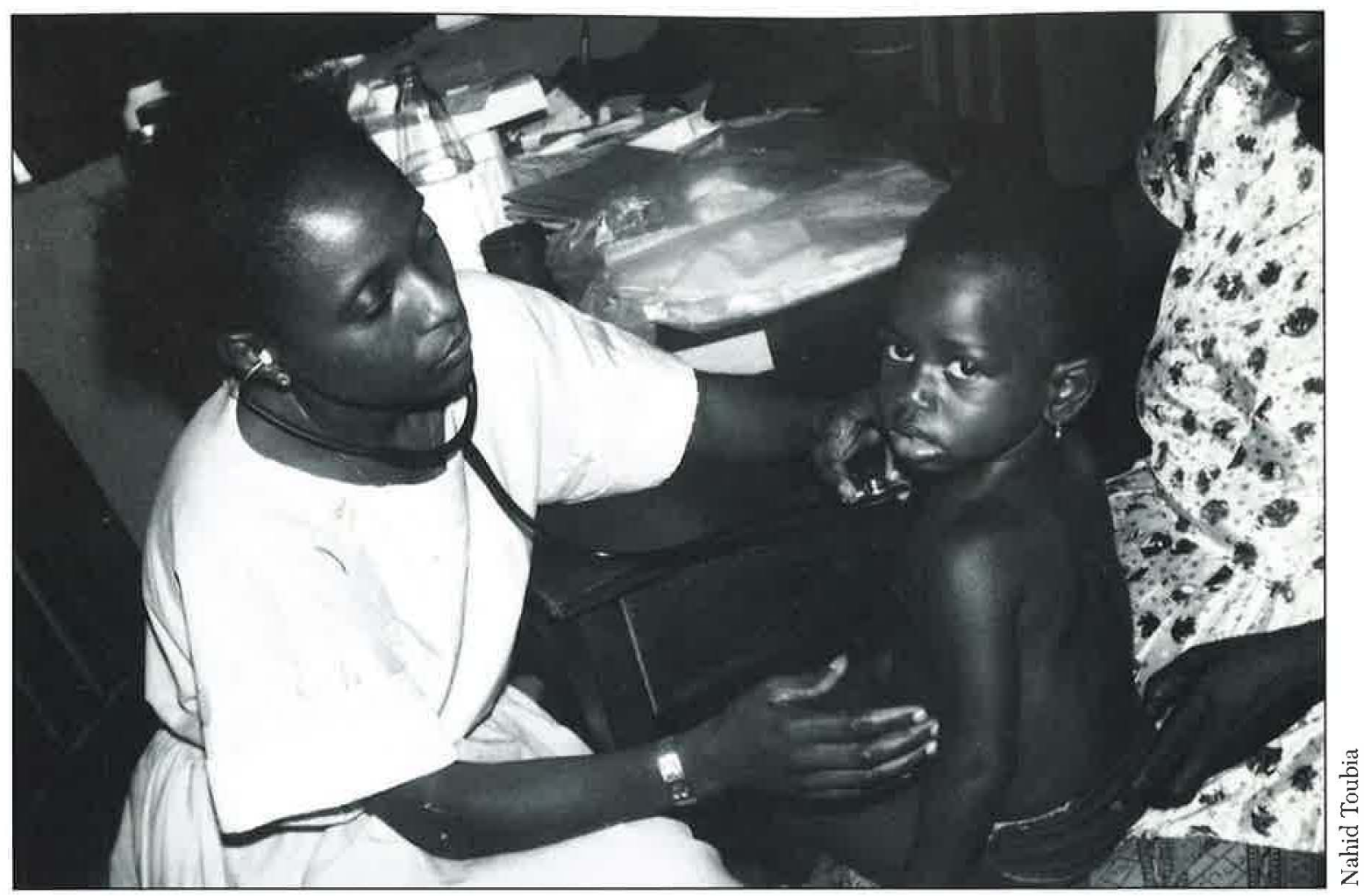

Another problem created by conditions of extreme economic hardship is the increased threat of burglary and violence. All MSSL buildings must be constructed with this threat in mind. Therefore, the openness and feeling of welcome that are an important part of the image of MSSL clinics must sometimes be compromised for the sake of security, at least in the capital city. In Freetown, strong wire mesh surrounds the dispensary and accounts payable sections where money is handled. Unfortunately, this creates barriers between clients and providers at these points in the clinic routine, but staff members try to compensate for this seeming unfriendliness with increased emphasis on personal warmth and affectionate gestures made at other times during client visits.

Increased security also entails extra cost. In 1990, burglars drilled through the clinic windows and stole the electric generator. The generator had to be replaced immediately (fortunately, donors came to the rescue), and a new room had to be built to house it more securely. In addition, the clinic has also had to employ a guard at night.
Despite these hardships, staff still try to cut costs by reducing consumption-something they have learned to do in their own homes, since no one in Sierra Leone can afford to be wasteful. Under such conditions of scarcity, conscious efforts at preservation, recycling and careful use of resources are not just an ideological exercise but a daily necessity. For example, the office secretary never discards a piece of paper that can be reused!

In poorly managed services, where employees are dissatisfied with their jobs, waste and misappropriation often occur. But MSSL's staff strongly identifies with the organization. They feel that the clinics belong to them and thus are as respectful of the clinics' property as they are of their own. Thus a fine balance is always kept between what is needed to sustain quality and what can be cut back on to prevent waste. What started as a philosophy has now became a daily habit for all the administrative, nursing and cleaning staff.

Most difficult of all unseen crises is a sudden devaluation of the currency and the accompanying change in the exchange rate. Besides raising prices (thus forcing increased charges 
for services), this creates a formidable accounting burden. For example, with each devaluation the staff must recalculate and average the costs of supplies purchased before and after the devaluation, as well as prices of items still in transit. Balancing the books, therefore, becomes a very difficult exercise. Computerization would simplify the process, and it is hoped that with the continuing improvement in Sierra Leone's power supply this can be a realistic option in the not-too-distant future.

\section{Maintaining Standards of Quality Care While Responding to Demands for Growth}

Despite all the difficulties, MSSL's services have not only survived but expanded. By the end of 1991, Marie Stopes Sierra Leone boasted two main clinics that provide a full range of services (including an operating theater in each) and eight satellite clinics.

The main clinics are located on Aberdeen Ferry Road in Freetown and in Port Loko, a town 76 miles north of Freetown. At the Aberdeen Ferry Road Clinic, a physician and nurse are available every day. Another full ser- vice clinic in Freetown on Adelaide Street lacks only an operating theater.

Access to all MSSL clinics is on a walk-in, first-come-first-serve basis. Although follow-up appointments are scheduled, clients can come in anytime between appointments if they feel the need. The main clinics are open Monday through Friday from 8:30 a.m. to 4:00 p.m., and on Saturday from 8:30 a.m. to noon to accommodate office workers. Clinic hours at satellite clinics vary with physicians attending on a rotational basis, since one physician may serve more than one satellite clinic.

Clinic hours and schedules are clearly posted at each site. Signposts identifying the location of the clinic are also strategically located in the streets surrounding each site. In addition, newspaper articles and radio programs frequently cite the location of MSSL services so that it not difficult for anyone in Freetown to know where to go for reproductive health care.

MSSL's eight satellite clinics offer limited services in different combinations, referring clients to the main clinies for services or contraceptive methods not available locally. Satellite clinics are located at strategic sites to

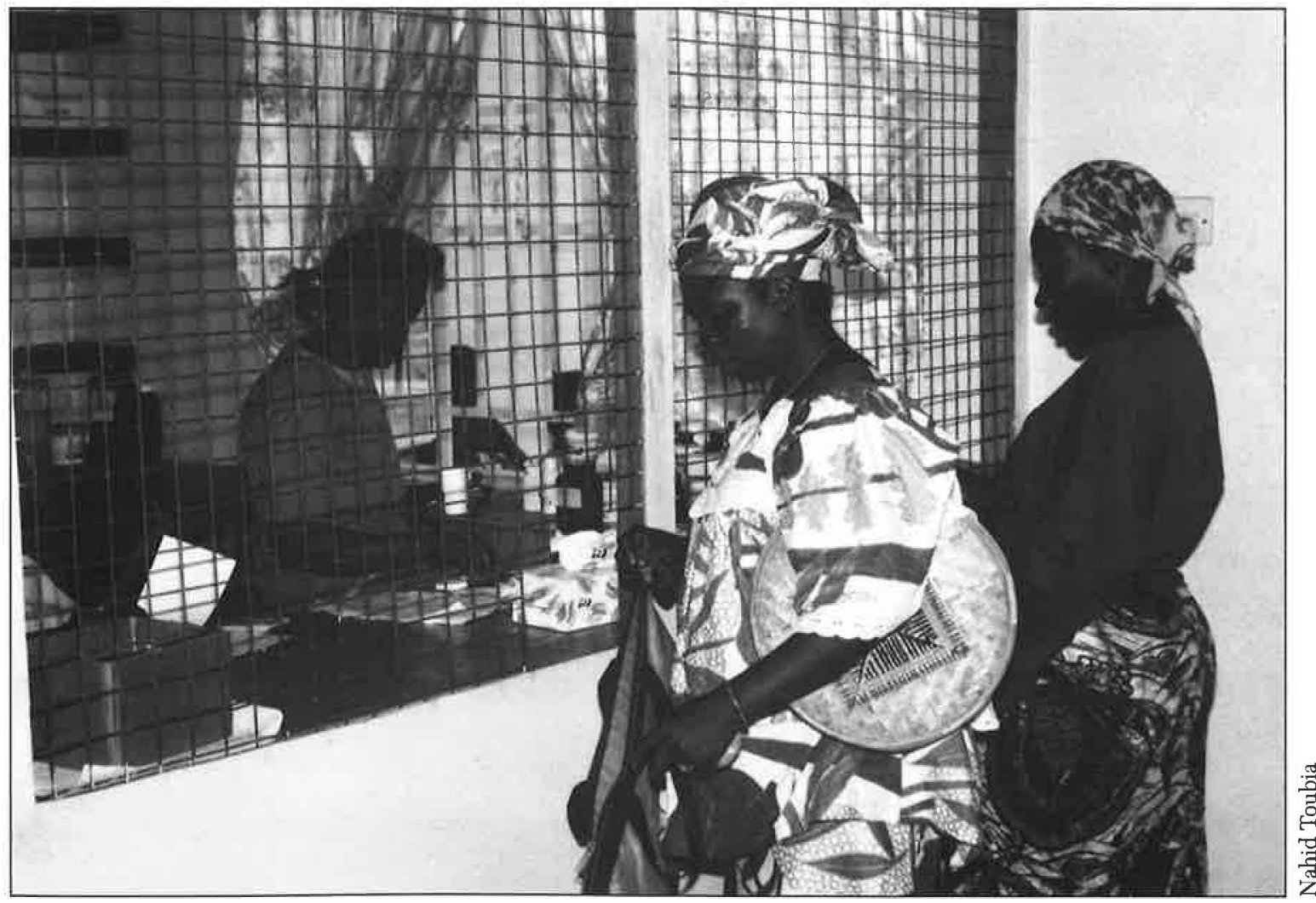


facilitate client access, including employmentbased health centers and employees' residential neighborhoods.

Employment-Based Services. Employment-based sites are important for two reasons: linking family planning to employment benefits gives a legitimacy to the services and, because employers pay a contribution to the cost of services, contraception is made affordable to lowincome employed families. In most cases, the employer also provides space for the clinic and covers maintenance and utility costs.

Currently, MSSL is collaborating with two major employers, the Port Authority and the police force. In a small, agriculturally-based country like Sierra Leone, with a long and accessible coastline, the Port Authority is the nation's single largest private enterprise, employing about 2,000 workers. Besides providing space for the family planning clinic, the Port Authority also covers most of the cost of services for its employees.

The police force clinics are located either near the main police health clinics or in the police housing barracks. The clinic buildings and all amenities are provided by the police force, but there is no reimbursement of client costs. Today three police clinics are in operation.

Services to Refugees. Recently, because of the rising problem of refugees fleeing from insurrections in neighboring Liberia, as well as within Sierra Leone, refugee camps managed by the Sierra Leone Red Cross have been set up. In response to the emergency, Marie Stopes Sierra Leone opened a tent in the camps to provide family planning and gynecological services. Since the Red Cross provides general health care, MSSL limits its work with refugees to family planning and STD and AIDS counseling and prevention. MSSL considers its work with refugees to be a long-term investment, since providing them with high quality services makes family planning a more attractive option. In addition, responding to a national emergency gives the organization visibility and respect.

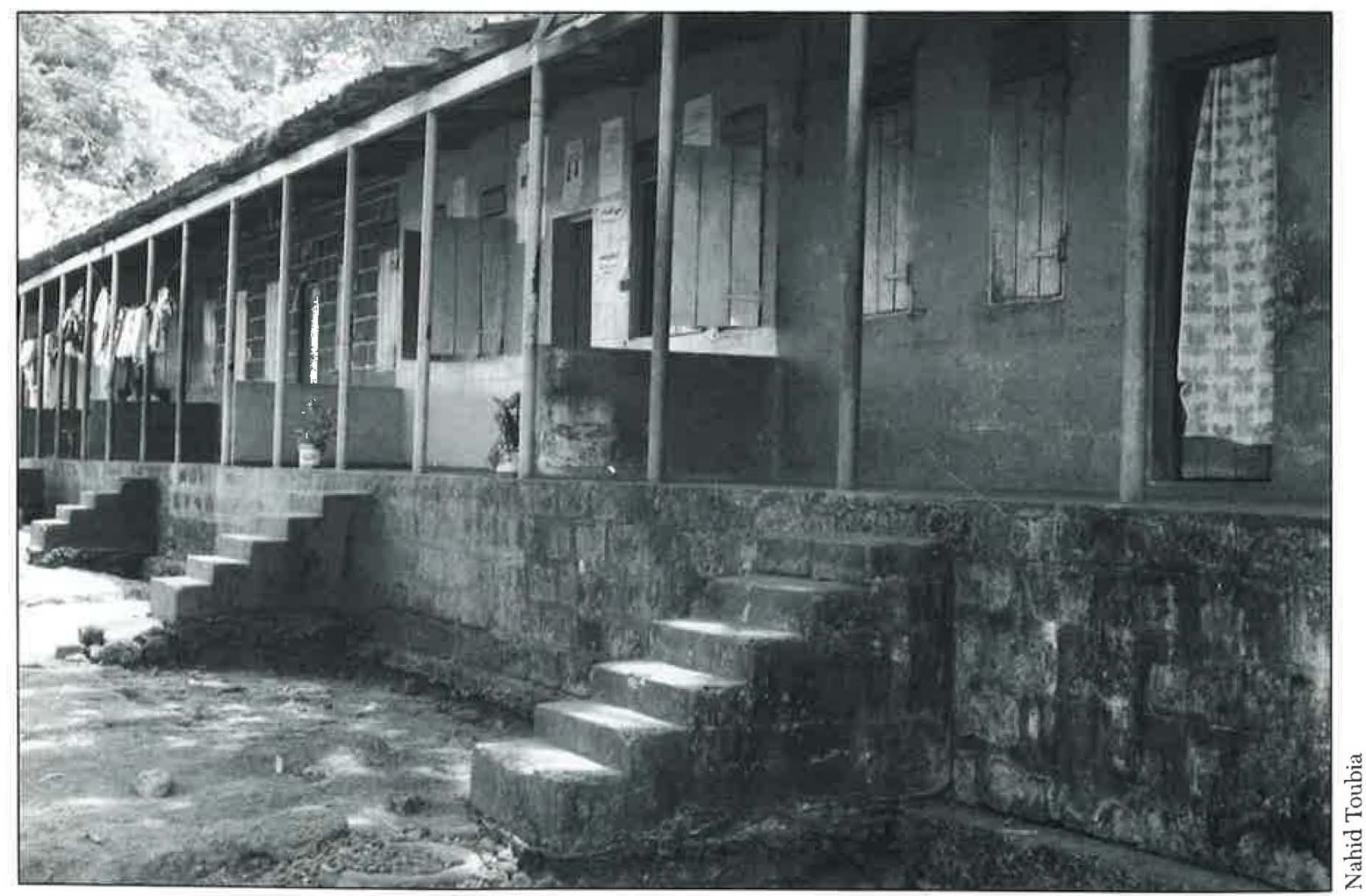




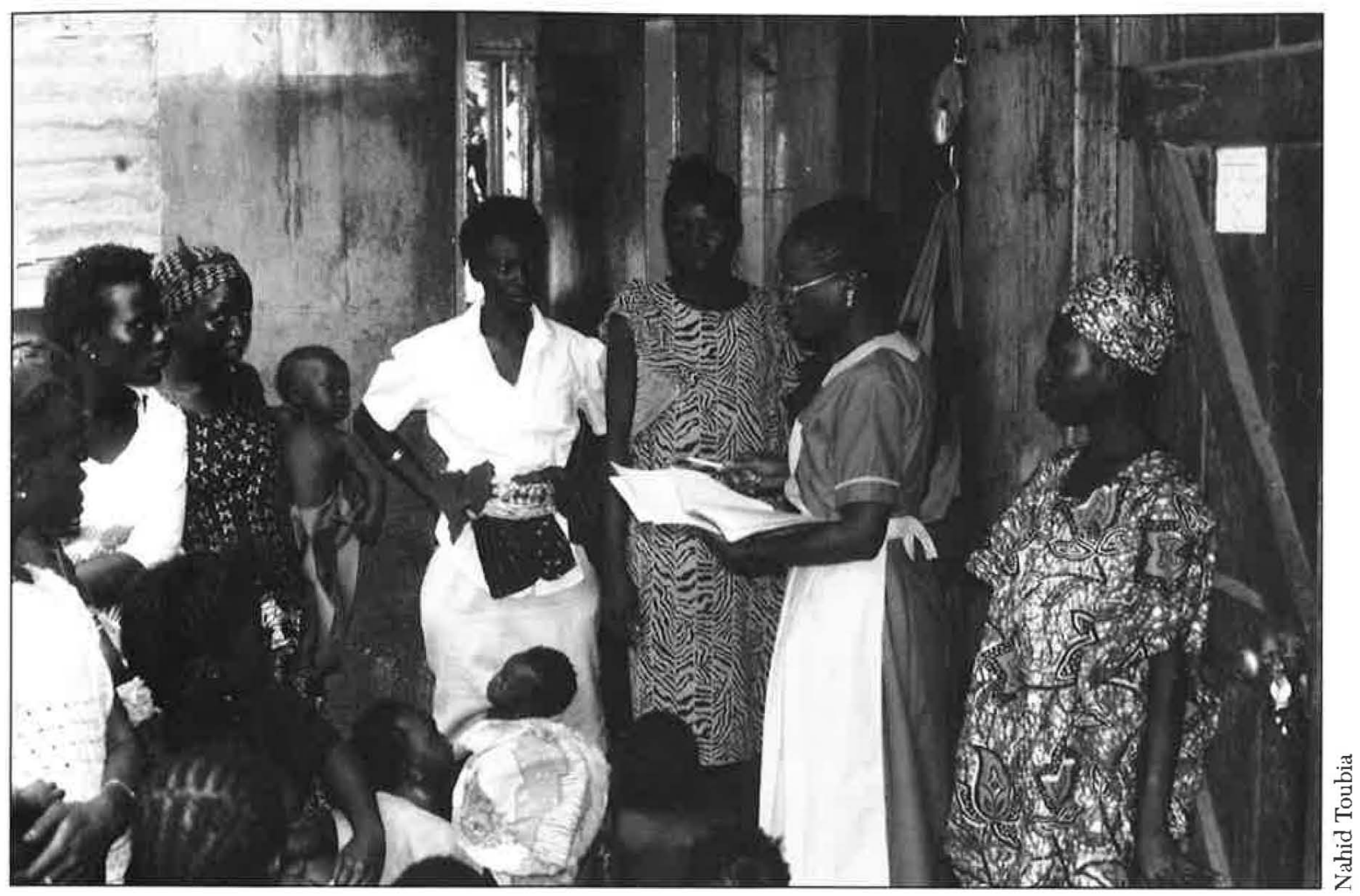

\section{The Importance of Effective Outreach and Community Involvement}

Because MSSL considers unplanned/ unwanted pregnancies and excessive childbearing to be a root cause of high morbidity and mortality among women of reproductive age in Sierra Leone, an important initial objective has been to generate awareness of family planning among the women of Freetown. A second objective has been to build a women's health program that could provide a platform from which to reach out to the women of Freetown with basic preventive medical care that includes an emphasis on child spacing.

Before the first clinic went into operation, traditional birth attendants (TBAs) and traditional social leaders, such as chiefs and "mama queens," were called together and informed about the Society's goals and objectives. MSSL staff explained how good reproductive health care can improve the quality of life for both women and men. Two weeks before the first clinic opened, MSSL placed advertisements in local newspapers and held meetings with women in marketplaces and bus stations to make them aware of the services that would be available.

On the day of the opening, there was a city-wide parade, with songs and banners introducing the clinic to the Freetown community. A special inaugural football gala was held at the National Stadium and a popular local newspaper published an article about Dr. Marie Stopes. An art competition on the theme "better health for all" was organized for college and senior secondary school students. Senior secondary school students also participated in an essay competition on the roles of women and men in family welfare. Similar activities continued throughout the year, including a theatrical production called "Sister Marie," staged by the Freetown Players, which emphasized the importance of family planning.

Initially three family planning pamphlets developed by the Marie Stopes organization in Kenya were reprinted for use in Sierra Leone. However, it was decided that too many ended up unread. Since then, advertising for the clinics and information about services have been printed on the covers of the exercise books sold to secondary school students and many students have subsequently come to the clinies as 
a result. The following information is printed in the books:

\section{MARIE STOPES CLINICS OFFER}

THE FOLLOWING SERVICES:

1. Comprehensive family planning

2. Pregnancy tests

3. Pathological tests

4. Maternal and child health

e.g. Prenatal care

Immunization

Growth monitoring

Nutrition education

Oral rehydration therapy

5. Gynecological consultation

6. Treatment of sexually transmitted diseases

7. Counseling

8. General health advice

\section{VISIT THE CLINIC IF YOU}

1. Have problems with irregular periods

2. Need education on the various family planning methods and guidance in making a choice

3. Are going through the hazards of an unwanted pregnancy and need guidance and counseling

4. Need information on maternal and child health: e.g. Vaccinations

Growth monitoring

5. Need treatment for sexually transmitted diseases

6. Are frustrated due to lack of communication

\section{MESSAGES}

1. If possible avoid sex before marriage

2. Seek advice from Marie Stopes Clinic if sexually active and need advice on contraceptives

3. Protect yourself from unwanted pregnancy

4. Avoid multiple sexual partners

5. Be aware that AIDS is around and is a killer disease

6. Be sure to immunize your child against the childhood killer diseases

7. Discuss all problems with trained youth leaders, counselors or visit the clinic

To date the most successful publicity and educational program sponsored by MSSL is a 15 minute weekly radio program in the local language, Krio, called "You en You Well Bodie" ("You and Your Health"). Produced by the Sierra Leone Broadcasting Service, the program presents discussions of important health and social topics such as: "The nature and causes of stress due to unplanned family size" and "Myths, misuse and abuse of contraceptives," by prominent women and leading health care providers in the community. Each program also provides information on various services offered at the MSSL clinics. At the clinics, tapes of these programs are played for clients in the waiting areas.

Grassroots leaders, both women and men, also participate in IE\&C activities. Indigenous elders and traders from selected areas of Freetown have been recruited and trained. For example, in Port Loko 300 men and women received intensive education in family planning, prenatal care, child care, STDs (including AIDS), personal hygiene, environmental sanitation and counseling and now act as field motivators. Their work is monitored by MSSL staff.

In addition, MSSL, in collaboration with the Department of Health, has provided training to traditional birth attendants (TBAs) in western Freetown. This area is far from the government hospital and most deliveries are performed by "grannies," as the TBAs are known locally. Twenty-five grannies came to the new obstetrics unit for three weeks in early 1993, to learn how to maintain good hygiene during delivery, when to refer a woman to the hospital and how to keep records. The "grannies" learned songs about the preparation of oral rehydration solution and the importance of immunization, and, through role playing, dealt with how to handle irresponsible fathers and call on the authority of the chiefs when necessary. The training program ended with an elaborate closing ceremony attended by local chiefs and health care officials as well as the trainees' family and friends. The TBAs were then presented with training certificates and a delivery kit. MSSL staff are now holding monthly follow-up sessions in which the TBAs can discuss any problems they encounter.

\section{A Humane Program of Cost Recovery}

All MSSL clinics aim to be self-sufficient, an important step toward achieving eventual independence from donor agencies. But in some locations, such as Port Loko, there is no way local people can afford the full cost of health care. In such situations, preventive measures such as family planning get pushed down to the bottom of clients' list of priorities. Thus donor contributions are still necessary to sustain the clinics. Grants from donors in international currencies also help to purchase supplies and spare parts from abroad. Local currency, primarily raised from clinic charges, can then be used to pay staff salaries and cover operating costs and procurement of local supplies. 


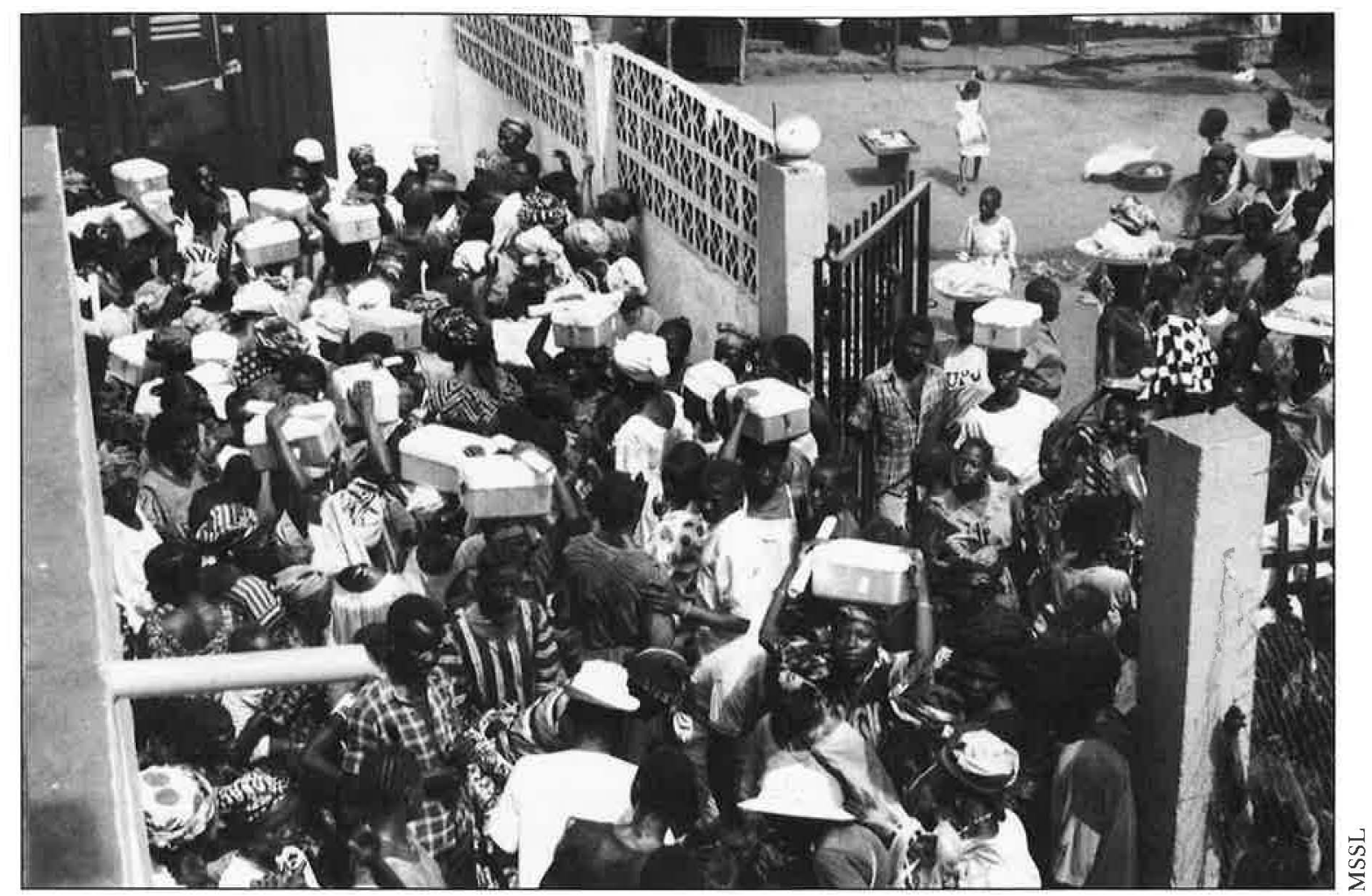

Currently, some MSSL clinics are 50 percent co-funded by the European Economic Community, with MSSL covering 35 percent of the costs and Marie Stopes International the remaining 15 percent. Several other clinics receive support from the British Overseas Development Administration.

Almost all of MSSL's contribution comes from clinic fees. The Society has tried other means of fund raising, but these have proven not only to be time consuming but ineffective as local people simply do not have extra money to spend. However, while many of the social events organized by Marie Stopes may have failed as fund raising mechanisms, they were successful tools for publicizing the clinics' services. MSSL also supports services such as family planning and child nutrition by charging more for curative health care. The highest charges are for adult medical consultations (other than family planning) at a cost of 700 Leones (US\$1.20). However, curative services for children are provided at half the adult rate. Thus by adjusting fees between curative care and preventive care-raising the former to subsidize the latter - and by stressing efficient use of resources, the organization has been able not only to sustain but actually improve the quality of its services. MSSL's experience has shown that clients are willing to pay a little more when they perceive that the services rendered are of high quality and constantly improving.

In an effort to encourage use of contraception, clients already registered for family planning could until very recently, get their general medical consultations free of charge. However, the Society has not been able to sustain this policy due to the rising costs of services. Currently, family planning clients pay only half the regular fee for general medical consultations.

As a not-for-profit organization, Marie Stopes tries to keep women's interests as its central goal despite the need for cost recovery. To cut costs and keep fees low, MSSL purchases most of its supplies from abroad through Marie Stopes International. However, this requires placing orders well in advarıce so supplies of contraceptives do sometimes run out. Every effort is made to restock the item immediately-even if this means purchasing commodities at a higher price in the local marketplace. 
Schedule of Fees and Charges (US $\$ 1=585$ Leonnes)

\begin{tabular}{|c|c|c|}
\hline Service & $\begin{array}{l}\text { Charges } \\
\text { in Leonnes }\end{array}$ & $\begin{array}{l}\text { Equiv } \\
\text { in US\$ }\end{array}$ \\
\hline Family Planning (yearly) - Adults & LE 180 & $\$ .31$ \\
\hline - Students & 70 & .12 \\
\hline STDS (per month) & 240 & .41 \\
\hline Antenatal (monthly) - per visit & 500 & .85 \\
\hline (throughout pregnancy) & 5000 & 8.55 \\
\hline Gynecological Consultation & 400 & .68 \\
\hline General Health Consultation - Adult & 700 & 1.20 \\
\hline - Student & 400 & .68 \\
\hline - Under 5 & 300 & .51 \\
\hline Card Fee & 90 & .15 \\
\hline
\end{tabular}

Note: There is a Special Medical Treatment Fund for the severely ill, under-fives and for clients with chronic STDs who cannot afford to pay for drugs.

When such a problem arises, the importance of the flexibility and trust that characterize the relationship between MSSL and the Marie Stopes headquarters in London becomes apparent. For example, when a large influx of new clients coincided with an acute shortage of oral contraceptives, the project director acted immediately and bought whatever pills were available on the local market. She later contacted the Marie Stopes office in London and explained the situation to them. Within a short period of time, MSI was able to provide funds from donors to cover the added cost. This level of mutual trust allows MSSL to act swiftly in a crisis - often the only way to handle the volatile conditions that result from a very unstable economy. In the context of Sierra Leone, complicated bureaucratic procedures and undue caution could easily bring a program such as MSSL's to an immediate halt.

Given the state of Sierra Leone's economy, the support of foreign donors remains critical. Without their assistance, MSSL would have to become a private for-profit company and charge much higher fees (estimated at a minimum of ten times the current rates) to cover all costs, including imported contraceptives and drugs. If this were to happen, MSSL's fees would be well beyond the reach of most Sierra Leoneans. Thus there would be fewer clients-probably not enough to even keep the organization in business.

\section{Clients' Perceptions Are the Strongest Advocate for Quality Services}

My friend said, "It [the clinic] is so good I cannot explain. Go ahead and you will see for yourself." As soon as I enter, the place feels like a clinic. It is tidy, neat and clean. You are seen by several people, reception, general checkup and then your family planning person. There is no waste of time, and you are constantly cared for.

31 year old primary schoolteacher, on her first visit to the clinic.

At the main clinic in Aberdeen, women start arriving at 8:00 a.m. It is still cool in the reception veranda overlooking the lush tropical surroundings and scattered banana fields. By 8:30 a.m., when the clinic opens, all the benches are filled. One of the nursing staff greets the women and gives them a 30 minute talk on the day's health or family planning topic. In the smaller clinics, a battery-run tape recorder takes the place of the nurse, since it can play throughout the day as the clients come and go.

After clients are registered, their clinic cards are retrieved or a new card filled out. Everyone gets a general checkup to measure their temperature, pulse and blood pressure; children have their weight and height recorded. Clinic staff believe strongly that such simple measurements help them to monitor their 


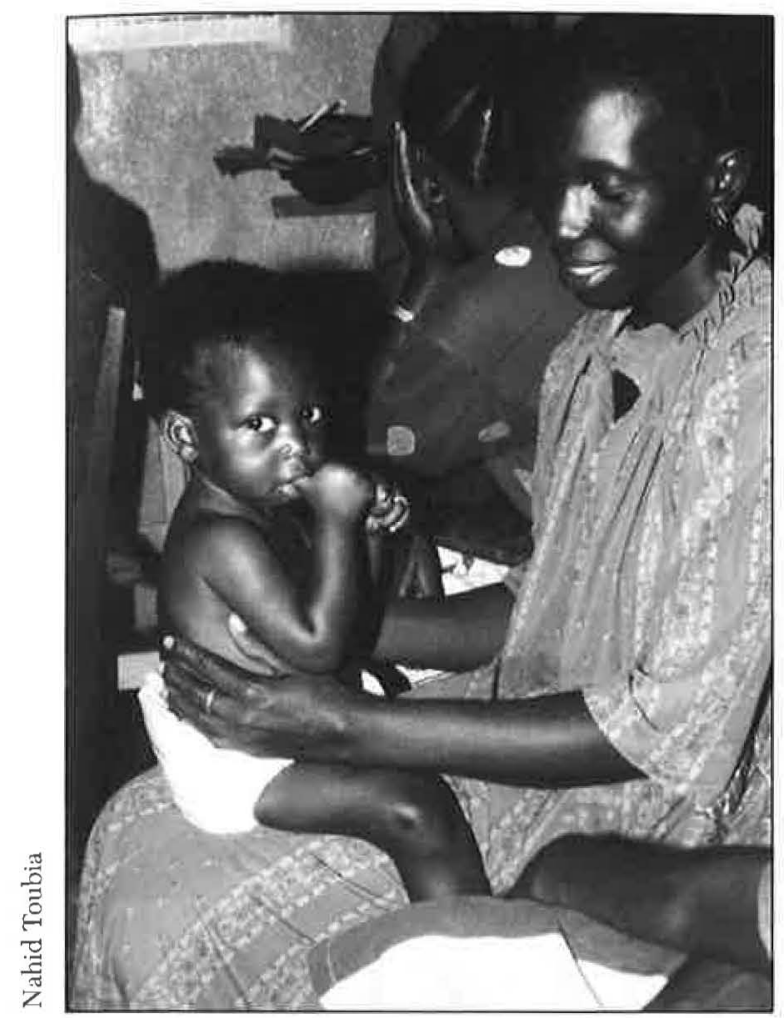

clients' health. For people who get little medical care, every opportunity should be taken to check their general health. This simple screening has proven to be lifesaving for many with undiagnosed high blood pressure and diabetes (which causes loss of weight). For family planning clients, these routine checkups help exclude contraindications to certain contraceptive methods.

Up until this point, all clients move in a single stream through the clinic. Family planning and other clients are in the general flow to ensure confidentiality. During the checkup, clients explain their reason for attending the clinic and are channeled to the appropriate service. STD treatment, family planning and general medical services are all provided in private rooms with doors that lock so that the client is ensured complete privacy.

The prenatal clinic has its own waiting area and an examination area separated by curtains. The immunization clinic is in a separate building at the far end of the back yard. Here mothers gather to cook for the under-five nutrition program. The waiting and recovery areas for surgical clients are impeccably clean, with five beds, armchairs, curtained windows, ther- mos flasks full of cold water and a rotating fan. Next to the operating room is an immaculately clean treatment area for dressings, injections and other minor procedures.

All MSSL clinics have their own sterilization equipment. In the small clinics, the nursing staff has been trained to operate portable kerosene-fueled autoclaves for sterilizing metal instruments and toweling. With the advent of the AIDS epidemic, the Society has employed more rigorous training in how to avoid cross infection, especially since needles and related items must be reused given the clinics' limited resources.

Before leaving the clinic, clients are directed to their last stop, the joint dispensary and cashier area. Here, prescribed drugs and/or contraceptives are dispensed and a cashier receives the payment for both the consultation and the dispensary fees. The accounting and bookkeeping is kept up-to-date, with an attention to detail comparable to that of commercial bankers. In the smaller clinics, the nursing staff are trained to fill prescriptions and perform the accounting functions.

Family planning counseling takes place in a closed room on a one-to-one basis. All meth-

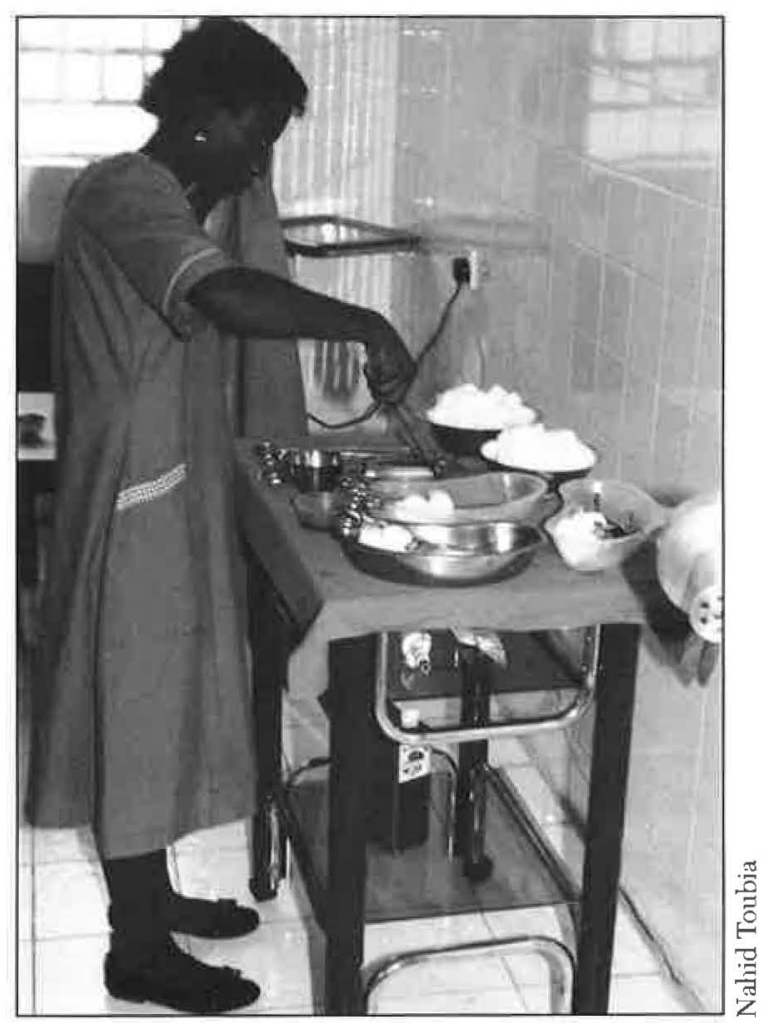




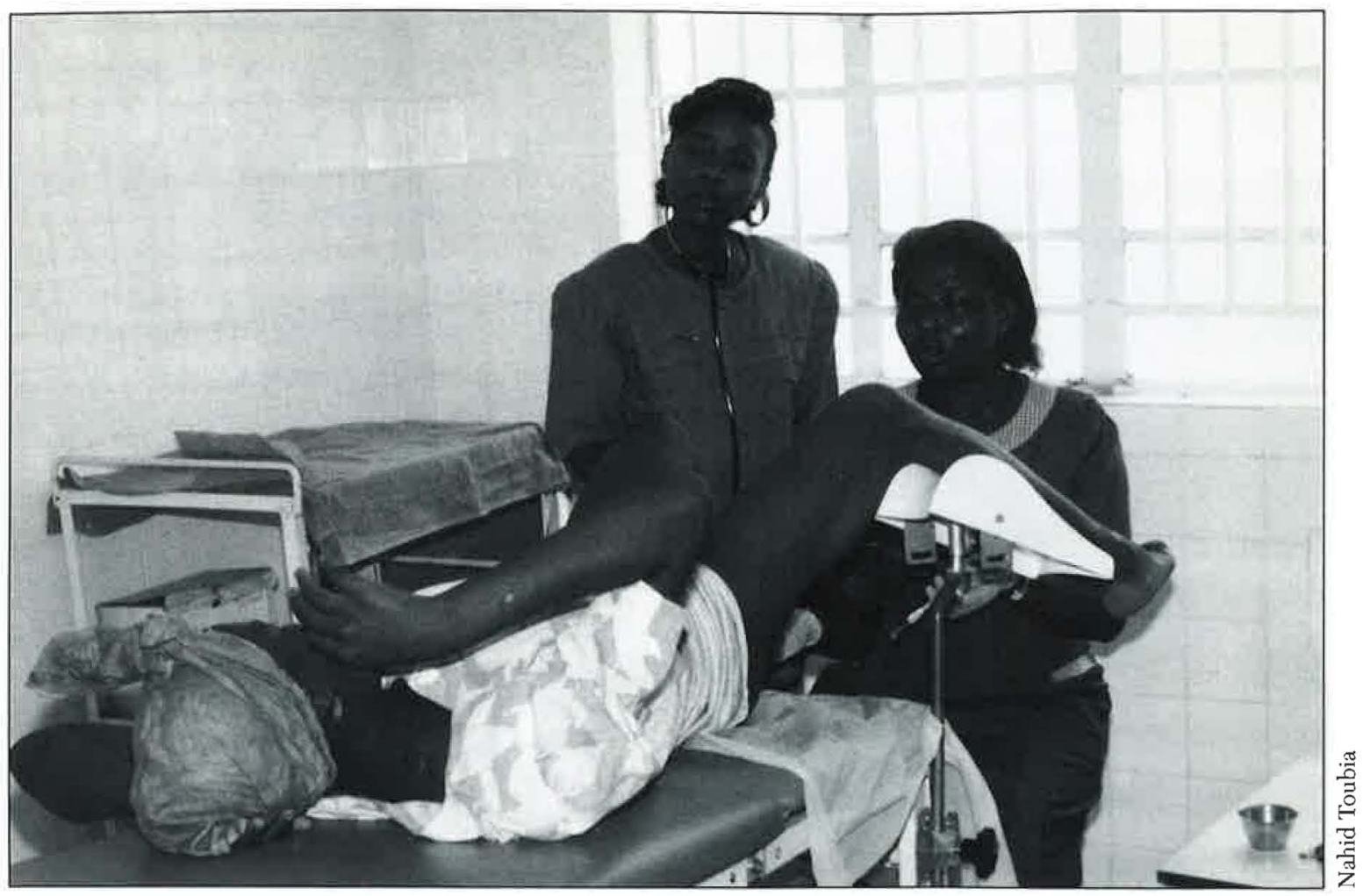

ods are offered, as long as supplies are available. Most women already have an idea of what method they want to try when they come to the clinic and this is the method they receive, if there is no contraindication. Throughout the consultation, both married and unmarried women are treated the same way; no consent from a husband or parents is required.

The pill is the method most commonly used by MSSL clients, followed by the injectable Depo-Provera. Only a one-month supply of pills is provided to the client after her first visit. Subsequently, she receives a twomonth supply and then a three-month supply is provided with each follow-up visit.

Although I know the women have already been told how to use the pill or the medication, I know they may not remember all the information. They have too much on their minds and this is new to them. I make sure I explain the use of all medications I dispense and confirm that the client absorbed it. It does not take that much time really.

Nurse/pharmacist at the Aberdeen Clinic
MARIE STOPES SOCIETY SIERRA LEONE SUMMARY CLINIC DATA January-December 1994

FAMILY PLANNING METHOD

\begin{tabular}{lr} 
Pill & 9,256 \\
Depo Provera & 7,177 \\
IUD & 730 \\
Condom & 2,472 \\
Foaming Tablets & 484 \\
Tubal Ligation & 44 \\
Other Family Planning Related Visits & 2,264 \\
\hline TOTAL & 22,427 \\
\hline
\end{tabular}

If the woman has any questions regarding side effects or possible complications, she can come back to the clinic at any time, without an appointment, and she will be given the necessary attention.

By August 1991, MSSL clinics were seeing about 4,000 clients per month. For many MSSL clients, general health issues-particularly acute illness-is their entry point to the service. But when they come, they learn about reproductive health, family planning, STDs and AIDS, prenatal care, and the importance of good nutrition for children and pregnant mothers. MSSL believes that family planning is 


\section{Marie Stopes Society Sierra Leone Yearly Family Planning Figures 1988-1994}

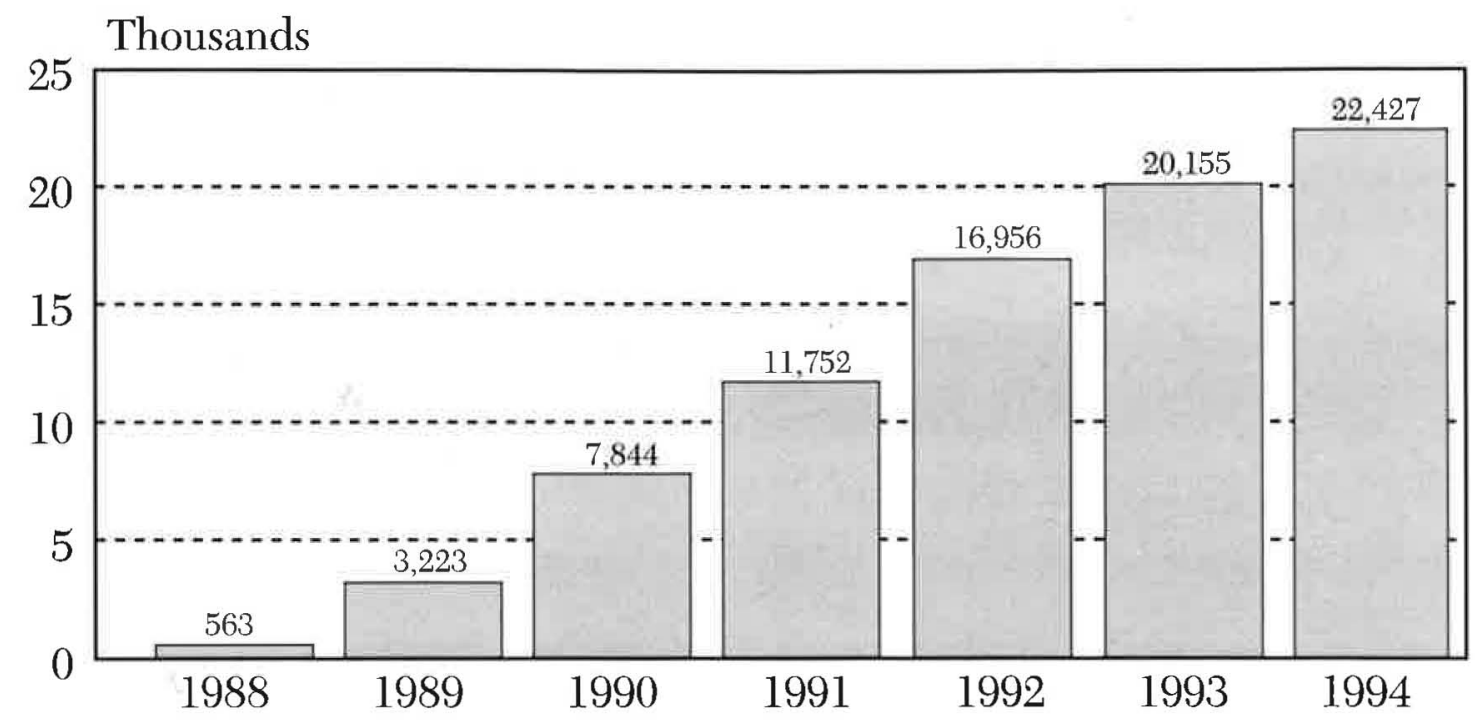

important for the health and well being of individuals and families, and that the best way to promote it is by increasing people's general and reproductive health awareness.

Reproductive health is a woman's right but we cannot yet pose it in these terms in our community. If you say "right" they will want to know who is wrong, who you are blaming and a fight will start.

\section{Sylvia Wachuku King}

\section{A Life Cycle Approach to Reproductive Health}

Young People. It is MSSL's goal to meet the reproductive health needs of Sierra Leonean women throughout their life cycle. Although not all the links are yet in place, they continue to move ahead one step at a time. For youth, there are educational and awareness campaigns. Through radio programs, talks and by showing videos in schools (using a portable generator), MSSL brings a discussion of sexuality to young people and advises them to try to postpone sexual activity until they feel they are ready. However, if they are already sexually active, they are encouraged to come to a MSSL clinic to talk about contraception and STDs and to get services.

There is now a network of eight MSSL Youth Clubs in the police barracks, with membership open to women and men between the ages of 16 and 24. In these clubs, they talk about contraception as well as prevention of STDs and AIDS. Having adolescents enrolled as members helps MSSL to follow up with young people who drop out of the clinics. The Society also organizes workshops, plays and singing groups for young people.

Largely because of the efforts of MSSL and other NGOs, AIDS and STDs have ceased to be taboo subjects in Sierra Leone and are now discussed openly. In the refugee camp, a youth singing group supported by MSSL popularized a song about the prevention of AIDS as part of its contribution to the International AIDS Day in December 1991.

The Youth Forum of the Fifth African Regional Conference held in Dakar, Senegal in 1994 stressed the need for special health services for youth. MSSL has always been aware of the these special needs. Unfortunately, at MSSL today young people still have to use the same clinics as adults; and although the clinics 
Sylvia Wachuku King comes from a modest middle-class Sierra Leonean family. She finished her high school education in Freetown. In 1969, she was awarded a grant to study at the State University of New York in the United States. She lived in New Paltz, in upstate New York, for the next seven years, finishing her BSC and MA in biology and working as the director of a residence hall at the women's dormitories.

During these years Sylvia gave much thought to issues of women's social and health problems and started to develop her skills as a counselor. In the residence hall where she worked, many women were experimenting with drugs and sex, and some of them became pregnant and were seeking abortions. Abortion had just become legal in the U.S. and was covered by college insurance plans. For Sylvia, it was good to see that women need not risk damaging their health when seeking abortion. By helping the students, she developed a deep interest in women's health and realized that, apart from

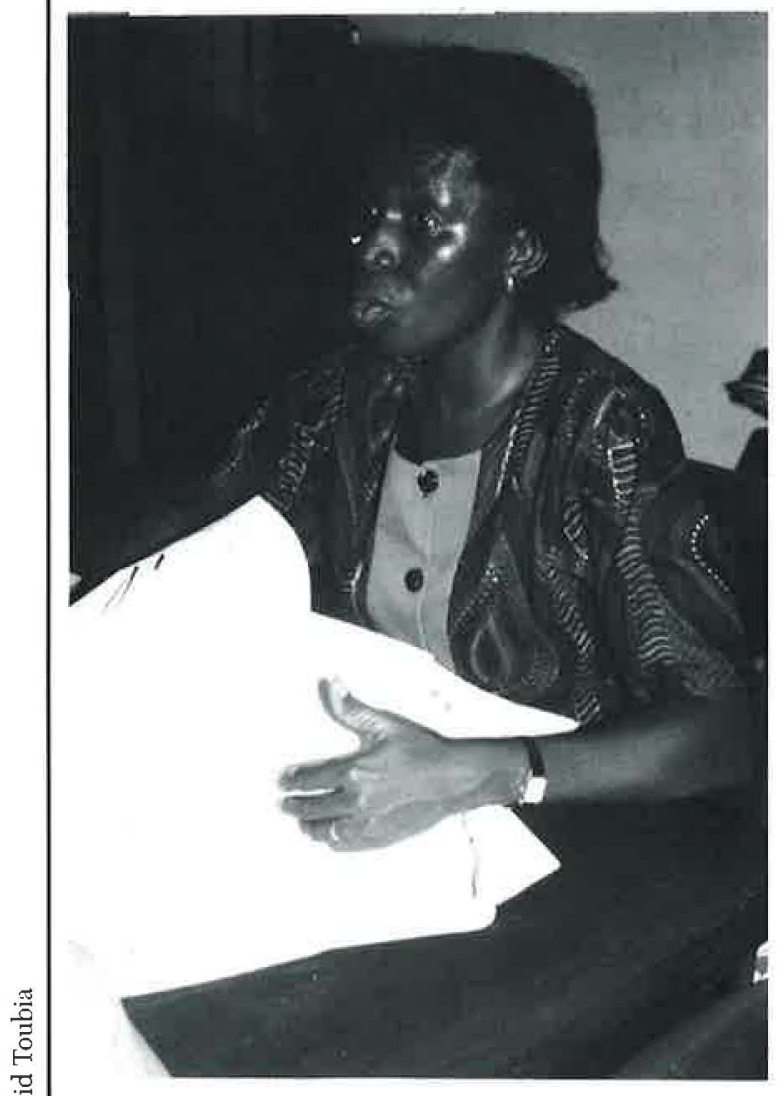

drug use, youth problems in the U.S. were not all that different from those in Sierra Leone.

Upon returning to Sierra Leone, Sylvia became a high school teacher with a goal of becoming a program director for a youth-oriented program. She reconnected with her society and deepened her understanding of its social and economic issues. She also continued to develop her counseling skills within her own community. But by 1987 she had become tired and felt confined by the school system curriculum. Besides, a school teacher's salary was hard to live on.

It was then that she answered an advertisement for a director of a women's health clinic. An EEC grant would cover the cost of establishing the clinic as well as staff salaries and operating costs for three years. Within weeks, Sylvia had the job. She had found what she was looking for.

However, it did not take long for her to realize what a challenge she faced. Sylvia set to work immediately, before initial support from Marie Stopes in London even arrived. "One can imagine being a project manager in Freetown in 1987 without an office, people and funds to manage!" Her first hurdle was just to find a site for the new clinic. One day while returning from a visit to a possible landlady, she fell into a hole hidden by a pool of water. "The scars on my knees can still be seen."

Despite the obstacles, and the skepticism of many friends and colleagues, Sylvia persisted. By December 1987 the new organization was registered with the Ministry of Social Welfare and by January 1988, six staff members had been hired. And that was just the beginning. When a friend likened her task to trying to fit a square peg into a round hole, she replied that with modern technology it is possible to do just that-to smooth the sides of the peg to fit the hole and then use what is left to fill in the gaps. "I may have been a square peg in a round hole, but I spared no time to fill in the gaps through training, learning from everyone no matter what their level, setting short and longterm goals, having a mind of my own and, above all, getting tremendous support from my family." 
have no age restrictions, many young people are still too shy or intimidated to attend. Sylvia King dreams of creating a youth center that will provide popular music, inexpensive food, games and a counselor who would be available for consultation. There would also be a room with a nurse who could provide services. As Sylvia notes, "This would be a great place for the kids who now stand bored in the streets." And judging by what the organization has already achieved, this dream may not be too far out of reach.

\section{Meeting the Broader Needs of Re-} productive Age Clients. When a woman becomes sexually active, she needs other gynecological services besides family planning. In addition to treatment of infections, the clinic provides Pap smears and treatment for infertility. Because there are few technologies available in Sierra Leone to investigate and treat infertility, the service concentrates on screening for simple problems, particularly infections, and treating them. For the more complicated cases, much effort is put into explaining the limitations of the infertility services available in Sierra Leone and in attempting to stop couples from falling prey to profit minded doctors, who push repeated and costly tests which offer little hope of tangible results.

The clinic provides counseling, offers support, and directs infertile couples, whenever possible, to other services. Unfortunately, some clients feel disappointed that they did not receive a miracle drug. "The most painful situation is when you suspect that it is the man who needs a sperm count," explains one of the nurses, "but it is very difficult to get the men to test their sperm." Dealing with the man in cases of infertility calls for tact and subtle persuasion. But sometimes it is impossible to convince him; instead, he keeps trying to prove his fertility by continually entering into relationships with new girlfriends.

Services for Menopausal and PostMenopausal Women. The clinic nurses are also very effective in providing counseling for menopausal women, but sometimes they need to refer them to MSSL's female gynecologist who has devised a special counseling technique for this situation. She helps the woman "flashback" to menarche and remember all the changes that happened to her then. In this way, she can see that menopause is only a returning to her original state, after she has completed her child-producing period. In the gynecologist's experience, much of the sadness associated with menopause actually comes from women's concern that their husbands will seek younger partners. Through counseling, MSSL staff try to make them aware that their days of sexual activity are not over and that it is culturally acceptable to continue having sex.

\section{A Space for Women That Includes Men}

Although MSSL's vision is to create a space where women feel at ease, they are very aware that women's lives are closely tied to both their children and their male partners. The organization's policy includes men and encourages them to be involved in the welfare of their partners and children. The decision to operate employment-based clinics was one step in that direction.

At employment-based clinics, each male employee is allowed to bring one woman and her children to the clinic, regardless of his marital status. (No more than one woman is allowed for each employee in order to safeguard against abuse.) To inaugurate the first such clinic, a big football match was organized to make the men feel involved. In addition, a drama group frequently visits the employment sites and performs for the men. Recently a drafts tournament (a table game similar to chess that is popular with men in Sierra Leone) was organized.

"We try to befriend the men so they are familiar with us," says Sylvia. "On any given day, at least one-third of the people in any of the clinics will be men. They bring their children, their mothers or accompany their wives. So although male contraceptive methods are not yet popular, many men have already been won over to the idea of family planning." 
In a further effort to increase men's knowledge of and participation in reproductive health care, MSSL recently opened its first Male Health Care Centre on Collegiate School Road in Freetown. Services offered at the men's clinic include: family planning (including vasectomy), general health care, counseling and treatment of STDs, counseling on HIV/AIDS and condom promotion and distribution. The clinic also stresses social responsibility and preventive health care by encouraging men to: learn about family planning and their role in making informed choices about family size and contraceptive methods; use condoms for both prevention of unwanted pregnancy and STDs; become more receptive to and understanding of maternal and child health issues; take advantage of both preventive and curative health care services available at the clinic; and recognize and accept responsibility for their roles in the family and community.

\section{Gaining the Respect and Trust of the Community}

Central to MSSL's mission is to hold a respectable position in Sierra Leonean society and to become part of everyday life. Articles on MSSL activities appear frequently in the daily newspapers, such as a recent issue of the New Citizen that featured a half-page article about MSSL winning the prize for the best monthly narrative report to its parent body, Marie Stopes International in London, while the Week End Spark reported on MSSL's activities in observation of International Women's Health Day. MSSL was instrumental in instituting May 28th as Women's Health Day - Sierra Leone, in response to the call of the Women's Global Network for Reproductive Rights in Amsterdam. Many local women’s organizations now participate in this annual celebration. For the first Women's Health Day Campaign, 12 women formed a committee to work on every aspect of women's health. They wrote to health providers and policy makers about their concerns. They also visited local markets with placards and talked to other women, individually or in small groups. Their message was:

Remember the 28th of May is the day when every woman should sit down and reflect on her health. If she needs help she must go and get it.
It is Friday afternoon on a mildly hot and humid November day. Brima Mansaray (age 27), who is a "chargie" or petty trader, arrives at the clinic with his wife, Fatima Kama (age 20). Brima sells local goods or food to the sailors on their boats in the port in exchange for imported goods like soap or toothpaste. Fatima sells fried food in the market. They have been married for eight years and have three children, ages nine, five and two. One child died in his first year. They are Muslims and live in Cline Town, about six miles outside of Freetown. The two older children are in school and Brima is taking care of the two-year old girl.

Fatima and Brima married young. They know they do not want any more children because life is becoming very hard for them; and, although they are both working, they are bringing less home every month. They have heard a little about family planning but are not quite sure about it.

Fatima wanted a girl after having three boys, one of whom died. She was fortunate to have a girl in her fourth pregnancy. But then she got pregnant again, and both she and Brima decided they could not afford to have any more children. They asked around for ways to deal with their situation. Someone directed them to the MSSL clinic in Cline Town, where they were referred to the clinic in Freetown.

While at the clinic, both Brima and Fatima had a long talk with the family planning nurse about different contraceptive methods. Today Fatima will leave with a packet of pills. She will then report to the Cline Town clinic for follow-up and refills so that another unplanned pregnancy can be avoided. When Brima was asked if he would use a method himself, he paused awhile, then responded, "Well, I would not mind. In fact, maybe I will prefer to use a method myself in case I am tempted to have a girlfriend. Then she cannot tie me down with a child or tell on me." (This conversation took place while Fatima was being attended to by MSSL staff.) 


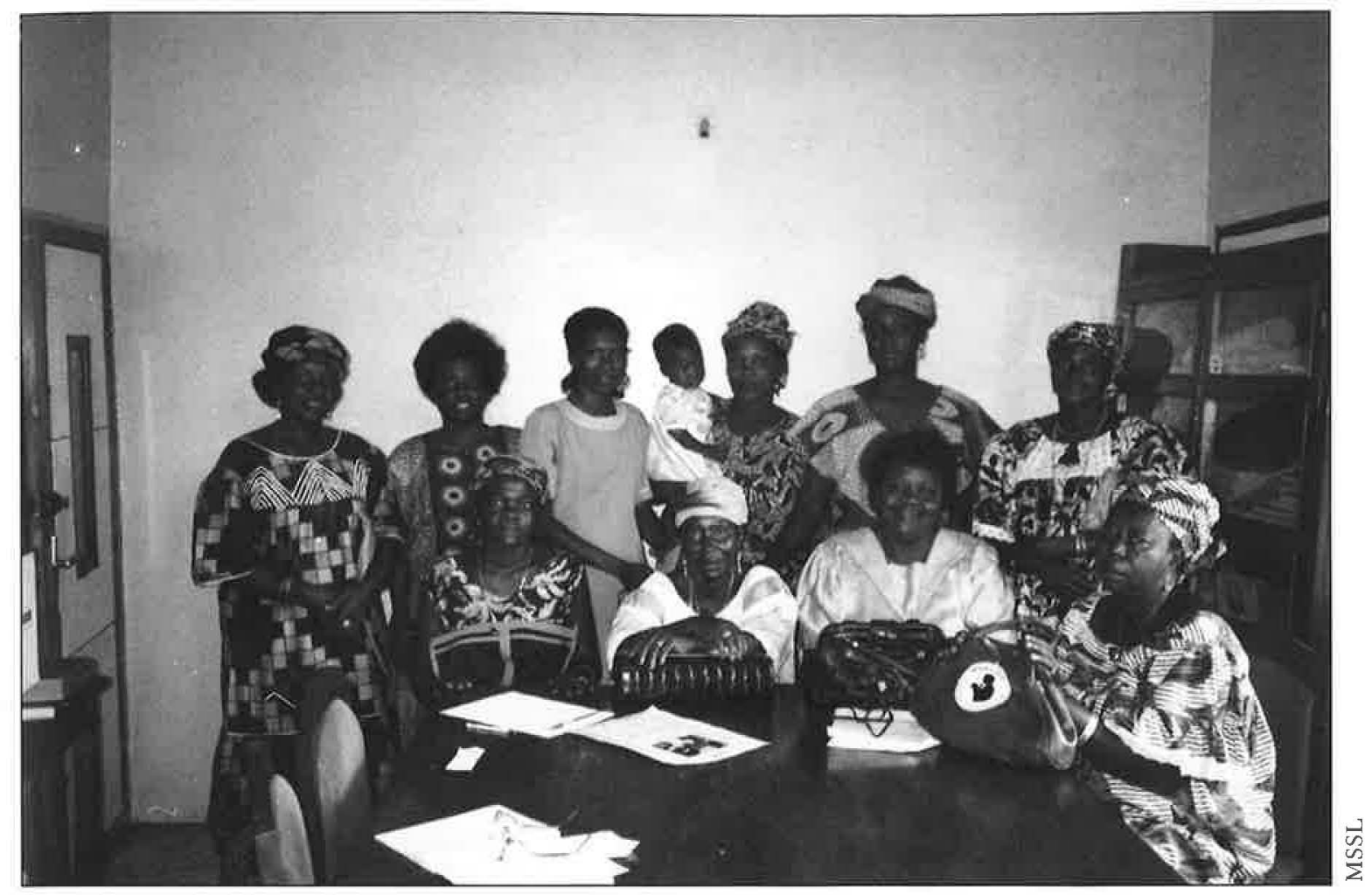

In the month following the campaign, MSSL's clinic intake rose by 40 percent. Some of those coming for the first time were market women who had never seen a health professional before. Routine checkups identified some of these women as having advanced hypertension. Their lives had been in danger because they were taking so many painkillers to relieve the headaches resulting from the high blood pressure. Thus, the 28th of May campaign may have saved their lives.

MSSL's community activities and its daily presence in people's lives are apparent everywhere. A few examples include: an annual Christmas party for clients and their families; designing and selling greeting cards; sponsoring essay and art competitions; holding a street parade to mark the fifth anniversary of the opening of the first clinic; a variety show for youth; raffle drawings; and sponsoring a police force football club that competes in league matches - it won the trophy in 1991.

The creative minds of MSSL's staff will keep generating new ideas to make health and family planning interesting, exciting and fun subjects for the people of Sierra Leone. Working closely with TBAs, local chiefs and opinion leaders (who serve as resource persons and motivators and provide services at strategic locations within the community), they will continue to seek ways to offer hope for the people of their country at a time when daily life is a constant hardship and the future is uncertain. For MSSL, the rewards are worth all of the hardships.

MSSL clinics have been pace setters in shaping the family planning program of Sierra Leone and will be held up as the standard by which all future services will be measured. Through MSSL, the people of Sierra Leone have been given a window of hope, a feeling that they can at least control some aspects of their lives and look forward to a healthier future. For those who work in the clinics, MSSL gives a purpose to their lives and creates a sense of pride in their work. 

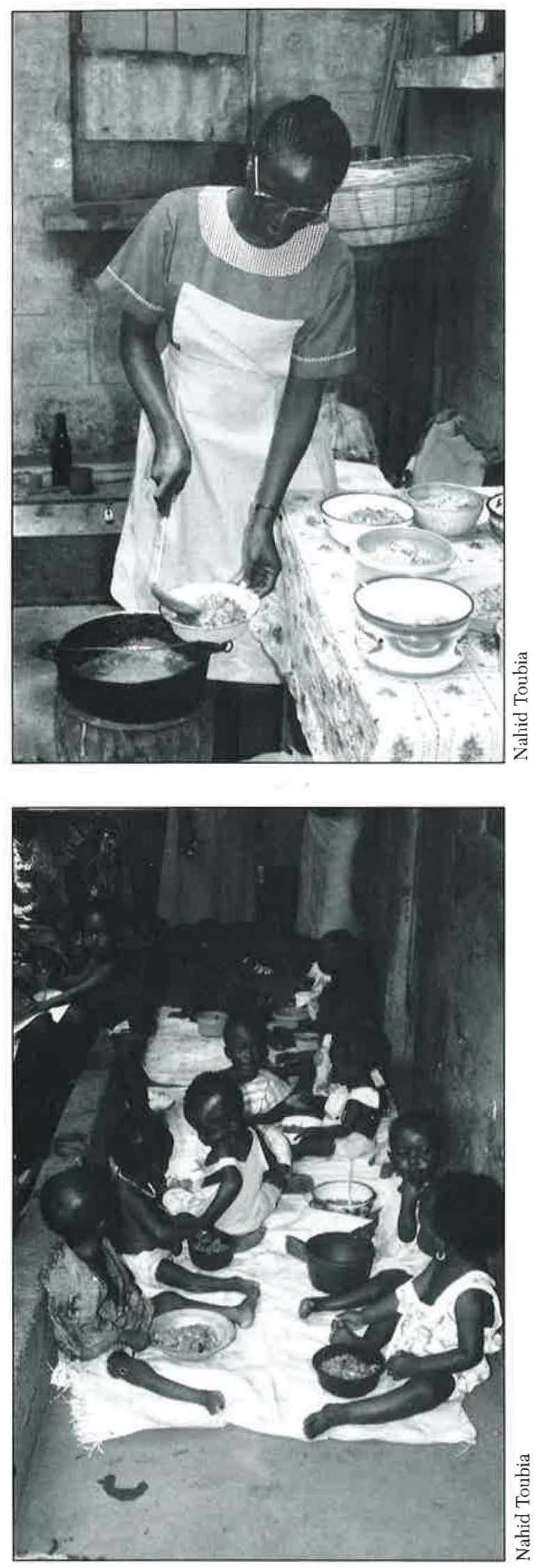

\section{Lessons Learned}

My experience as author of this edition of Quality/Calidad/Qualité on the Marie Stopes Sierra Leone organization was both stimulating and inspiring. The organization pursues its goals with an astonishing amount of compassion and ambition, despite seemingly insurmountable economic hardships. In fact, I found it difficult to evaluate and summarize the organization's programs because of the momentum and velocity with which they expanded and evolved, even during the short period of my observation. Although Sierra Leone's political and economic problems create hardships and instability, the extent and quality of the MSSL's work nonetheless remains extraordinary. My work with the Sierra Leone clinic was educational at a variety of levels, but several particularly important lessons emerged.

1). While severe economic hardship seriously affects the ability to maintain quality health care services, creative, skillful management, well-organized and flexible financial administration, and human motivation and perseverance can enable an organization to overcome financial difficulties and achieve remarkable goals.

2). Family planning is an integral part of people's reproductive and general health concerns. Therefore, in places where general health care services are scarce, a comprehensive, integrated program of reproductive and general health care services is essential to meeting the needs of the community.

3). A wide choice of fertility regulation services need not be compromised by scarcity of supplies. A staff that is trained to act creatively and flexibly in offering the widest variety of choices available can almost always provide people with services that allow them to be comfortable, safe and healthy.

4). Concern for reproductive health can dovetail with concern for development in useful and practical ways. Health service personnel can be important agents of social change. Because of their status as knowledgeable caregivers, their attitudes hold a great deal of influence, and they are in a position to disseminate information widely. 


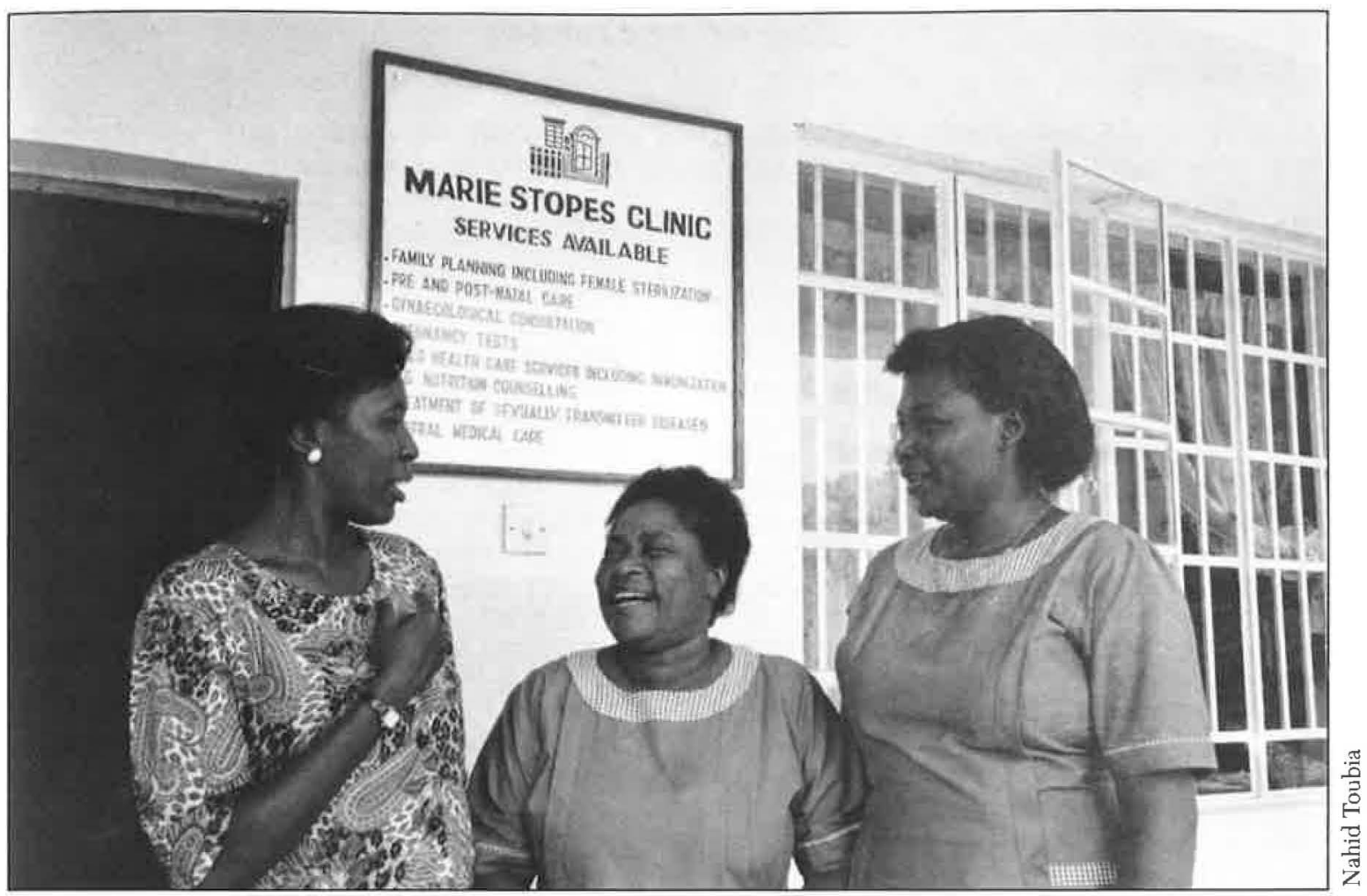

5). Men appreciate being involved in the care of their children and their female partners. Including men in the process of family planning and educating men about reproductive health care-their own and their partners-encourages better communication around fertility choices and more successful family planning programs.

6). A woman-centered reproductive health care service can help empower women to care for and value themselves. It can also act as a comfortable venue for the introduction and discussion of women's rights issues in a non-threatening environment. 


\section{Résumé en Français}

A travers l'Afrique, une des principales causes de mortalité et de morbidité maternelle, est un taux de fertilité élevé. Pour la Sierra Leone, un état de l'Afrique de l'Ouest, la situation est encore plus précaire à cause du déclin économique, de l'instabilité politique, et du retrait d'une grande partie de l'assistance intemationale au développement. Le taux d'alphabétisation baisse et de nombreuses régions du pays n'ont pas de services médicaux et encore moins de services de planification familiale.

Marie Stopes Sierra Leone (MSSL) a ouvert sa première clinique dans la capitale, Freetown, en mars 1989. Sous la direction dynamique de son directeur, Sylvia Wachuku King, MSSL s'est développée et comprend maintenant deux bureaux principaux et huit cliniques satellites. MSSL a également mis des services cliniques à la disposition de plusieurs grands employeurs du pays (tels que l' Autorité Portuaire et la Police), et offre des soins aux réfugiés fuyant la guerre civile qui se déroule dans le pays voisin, le Liberia.

Concernant la santé génésique, même les soins primaires ne sont pas disponibles ou ne sont pas à la portée de la plupart des Sierra Leonais; ainsi MSSL a adopté une approche intégrant la planification familiale, le traitement des maladies sexuellement transmissibles, les soins prénatals et les procédures gynécologiques simples ainsi que les soins généraux de santé, en particulier pour les enfants de moins de cinq ans. Cet intérêt pour la santé générale des individus a permis à MSSL de satisfaire ses clients et de gagner leur confiance: le client moyen visite une clinique environ quatre à cinq fois par an pour divers services.

De plus, les hommes ne sont pas exclus par MSSL. Au début, ceux-ci sont venus surtout pour accompagner leurs partenaires ou des membres de sexe féminin de leur famille. Ultérieurement, à cause de l'acceuil positif qu'ils ont reçu, ils sont venus tout seul pour le traitement des maladies sexuellement transmissibles et de l'infertilité. En fait, MSSL est devenue tellement efficace à répondre aux besoins des hommes qu'elle a récemment ouvert sa première clinique "pour hommes seulement" à Freetown.

Le champ des services offerts par les cliniques de MSSL continue à s'élargir en fonction des besoins des clients. Au début, une classe ayant pour sujet la nutrition des enfants de moins de cing ans a été organisée, peu à près, elle comprenait également la nutrition des femmes enceintes et malnourries. Lintroduction d'examens de laboratoire permet maintenant à MSSL de faire des Pap smears et des tests pour les maladies sexuellement transmissibles. Les médicaments et les contraceptifs sont disponibles à des prix très modestes. Les clients qui ne peuvent pas payer ne sont jamais renvoyés ou refusés des médicaments et, parce que les prix sont si bas, cette situation arrive très rarement.

Au milieu de 1992, MSSL a établi une unité ostétricale dans sa clinique principale à Freetown. Cette clinique servait également de centre pour le programme "Maternité sans risque". Une gamme complète de services prénatals, maternels et postnatals était offerte, et une unité de dix lits ouverte vingt-quatre heures sur vingt-quatre pour les accouchements. En 1993, une salle d'opération fut ajoutée pour que les Caesariennes et autres procédures chirurgicales puissent être faites sur place. MSSL a également adopté une approche relative au "cycle de vie" afin de répondre aux besoins des femmes en santé génésique, approche incluant les services pour les adolescentes et les femmes à la ménopause.

Tout ceci à été accompli en dépit de la crise économique, des dévaluations fréquentes de la monnaie, et de toutes sortes de crises. Le staff de MSSL est devenu étonnemment ingénieux dans sa détermination à donner des soins de qualité dans un environnement ou seul maintenir un stock adéquat de fournitures est une tache formidable: des contraceptifs et des médicaments aux antiseptiques, savons et fournitures de bureau.

MSSL a toujours travaillé très près de la communauté: les leaders d'opinion et les membres influents de la société participent à de nombreuses activités; de plus elle s'est servie des médias de manière efficace pour éduquer les membres de la communauté sur la santé. MSSL a également de bonnes relations de travail avec les ministères du Gouvernement et les groupes civiques.

Bien que toutes les cliniques MSSL ont pour but d'être indépendante financièrement, le recouvrement des dépenses ne sera pas possible pour longtemps à cause de la pauvreté de la plupart des clients. Peut être il ne le sera jamais. MSSL dépend de l'assistance financière des bailleurs de fonds internationaux qui pourvoient les devises dont elle a besoin pour acheter, à l'étranger; les fournitures et pièces détachées. Les frais de clinique, en monnaie locale, servent à payer les salaires et à couvrir les couts d'opération. Le support positif et flexible que MSSL reçoit de son bailleur de fonds principal, Marie Stopes International de Londres, a été crucial pour aider l'organisation à traverser les fréquentes crises qui arrivent dans un milieu économique aussi instable. Qu'ils aient pu continuer non seulement à fonctionner, mais à offrir des soins de qualité, tout en élargissant la gamme de leurs services selon les besoins des clients, est tout simplement stupéfiant. Marie Stopes Sierra Leone a établi un standard que bien des programmes, évoluant dans un environnement ou les ressources sont rares, pourraient chercher à émuler. 


\section{Resumen en Español}

En Africa, el alto nivel de fecundidad es uno de los factores que más contribuye a la mortalidad y morbilidad materna. Las mujeres de Sierra León, en el oeste africano, cargan además con las consecuencias del deterioro económico, la falta de estabilidad política, y la reciente desaparición de casi todo el apoyo internacional para el desarrollo. Los niveles de alfabetización de Sierra León están en descenso, y muchas de sus regiones han quedado sin atención médica alguna, ni hablar de servicios de planificación familiar.

La organización Marie Stopes Sierra León (MSSL) inauguró su primera clínica en Freetown, la capital del país, en marzo de 1989. Bajo la dinámica dirección de Sylvia Wachuku King, la MSSL ha crecido a tal punto que opera dos oficinas principales y ocho clínicas satélite. La MSSL también provee servicios clínicos para varios grandes empleadores en Sierra León-entre ellos la administración de puertos y la policía-además de suministrar atención médica para refugiados de la guerra civil en Liberia, un país vecino.

Dado que los servicios de salud básicos no existen o están fuera del alcance de la gran parte de los habitantes de Sierra León, la MSSL ha adoptado un systema integral de atención que incluye planificación familiar, tratamiento para enfermedades de transmisión sexual (ETS), atención prenatal y procedimientos ginecológicos simples. Estos servicios complementan una base de atención médica general, especialmente para niños menores de cinco años. Como consecuencia de esta preocupación por el bienestar total del individuo, la MSSL ha logrado satisfacer y ganar la confianza de sus clientes, que típicamente visitan la clínica entre cuatro y cinco veces por año.

Es más, la MSSL no excluye a los varones. Al principio éstos venían principalmente para acompañar a sus parejas o parientes. Pero a medida que vieron que eran bien recibidos, muchos hombres empezaron a venir por su cuenta para recibir tratamiento para las ETS o problemas de infertilidad. De hecho, la MSSL ha respondido tan bien a las necesidades de los hombres que recientemente abrió su primera clínica "sólo para varones" en Freetown.

La gama de servicios ofrecidos por las clínicas de la MSSL sigue creciendo en reconocimiento de las necesidades de los clientes. Casi desde el principio se ofrecieron clases sobre la nutrición de niños menores de cinco años; más tarde éstas fueron ampliadas para incluir mujeres embarazadas que padecen de desnutrición. La introducción de prue- bas de laboratorio ahora permite que la MSSL ofrezca exámenes Papanicolau y pruebas para las ETS. Una pequeña farmacia provee medicamentos y anticonceptivos a bajo precio. A los clientes que no pueden pagar nunca se les niega un servicio, pero dado que los honorarios son tan económicos, esta situación casi nunca se presenta.

Para mediados de 1992, la MSSL estableció una unidad de obstetricia en su clínica principal de Freetown que también sirve como Centro Para la Maternidad sin Riesgos. Esta unidad, que funciona 24 horas por día y cuenta con una sala de partos con diez camas, ofrece una gama completa de servicios prenatales, maternos y posnatales. En 1993 se agregó una sala de cirugía para la ejecución de partos por cesárea y otros procedimientos quirúrgicos. La MSSL también ha adoptado un filosofía de servicios orientada hacia el ciclo entero de la mujer, en el cual se incluyen servicos tanto para adolescentes como para mujeres que atraviesan la menopausia.

Todo esto se ha logrado en un entorno de crisis económica, frecuentes devaluaciones en la moneda nacional, y la falta contínua de abastecimientos básicos como el jabón, los antisépticos y el papel, además de anticonceptivos y remedios. A pesar de todo, el personal de la MSSL ha encontrado maneras de mantener su compromiso con la provisión de servicios de alta calidad.

La MSSL siempre ha trabajado estrechamente con la comunidad entera, solicitando el apoyo de personajes influyentes y utilizando los medios de comunicación para educar al público sobre la salud. La MSSL también cultiva buenas relaciones con los ministerios del gobierno y con varios grupos cívicos.

Aunque todas las clínicas de la MSSL tratan de ser autosuficientes, la pobreza de la mayoría de sus clientes hace casi imposible la recuperación total de los gastos. La MSSL depende de donantes extranjeros para comprar suministros importados. Los honorarios que las clínicas reciben de los clientes son utilizados para pagar sueldos y cubrir los gastos de operación. El apoyo positivo y flexible que la MSSL, recibe de su donante principal, Marie Stopes International en Londres, ha sido indispensable para la supervivencia en un ambiente de crisis económica. El que la MSSL no sólo haya logrado seguir operando, sino que lo está haciendo con altos niveles de calidad y una ampliación contínua de los servicios, es poco menos que increíble. La MSSL ha establecido una modelo de servicio que muchos programas en países más ricos deberían tratar de imitar. 


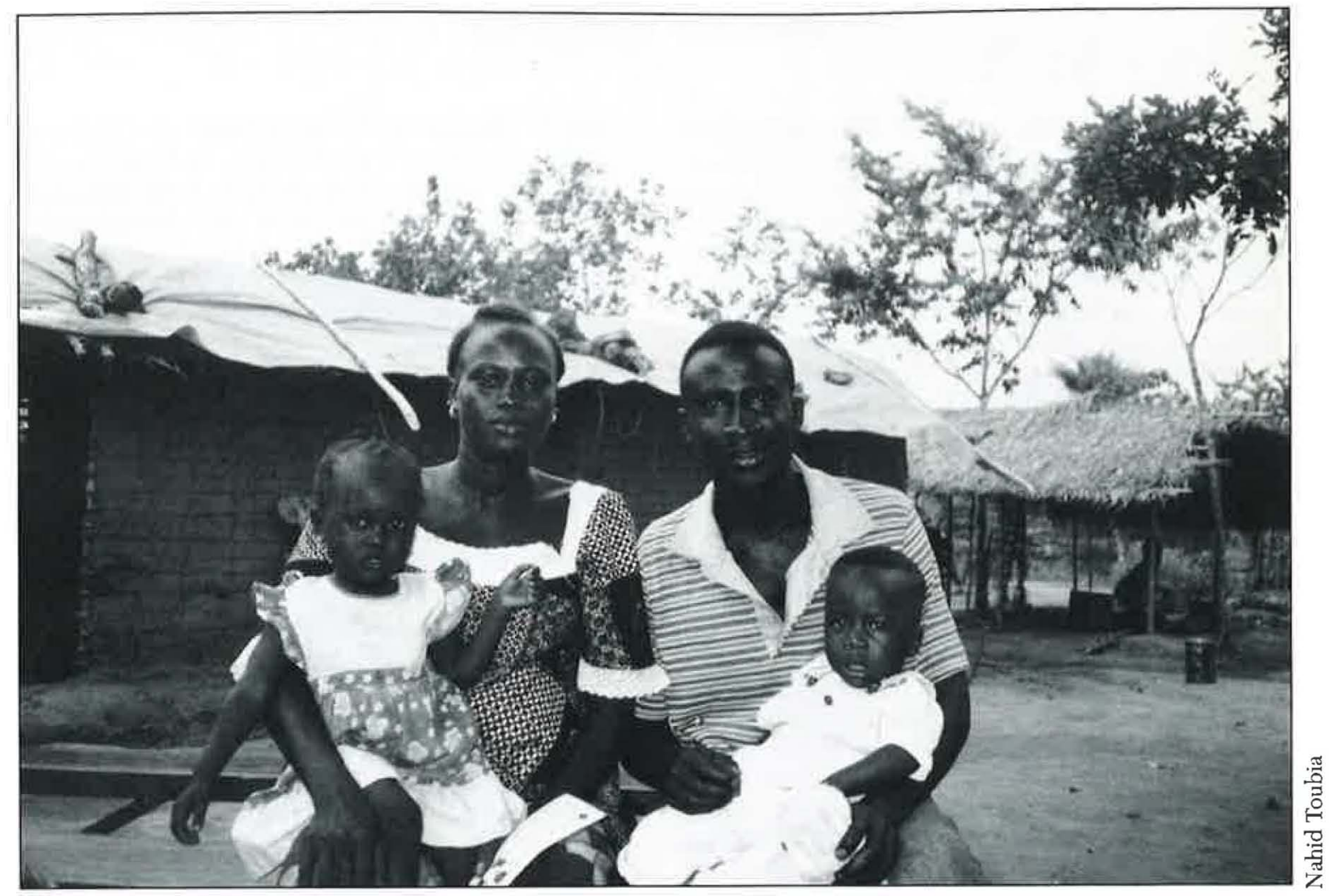

\section{Other Issues of Q/C/Q Currently Available}

1. Celebrating Mother and Child on the Fortieth Day: The Sfax Tunisia Postpartum Program (English; text in Spanish and French available in typewritten format)

2. Man/Hombre/Homme: Meeting Male Reproductive Health Care Needs in Latin America (English and Spanish.)

3. The Bangladesh Women's Health Coalition (English)

4. By and for Women: Involving Women in the Development of Reproductive Health Care Materials (English)

5. Gente Joven/Young People: A Dialogue on Sexuality with Adolescents in Mexico - (English)

6. The Coletivo: A Feminist Sexuality and Health Collective in Brazil - (English) 


\section{About the Authors}

Nahid Toubia is a physician from Sudan. As a practitioner in her country for 15 years, she has also experienced many similar hardships of operating under deteriorating economic conditions. as those she witnessed in Sierra Leone. Formerly an Associate for Women's Reproductive Health at the Population Council, she is currently a professor in the School of Public Health at Columbia University and director of a new NGO, Rainb?, focusing on issues of women's reproductive health and rights.

Grace Delano is a Nigerian nurse-midwife. As Principal Nursing Officer in the Department of Obstetrics and Gynecology at the University College Hospital in Ibadan, she was involved in numerous research and training programs in the areas of family planning and reproductive health. Currently she is Vice-President and Executive Director of the Association for Reproductive and Family Health in Ibadan, Nigeria.

\section{Quality/Calidad/Qualité Advisory Committee}

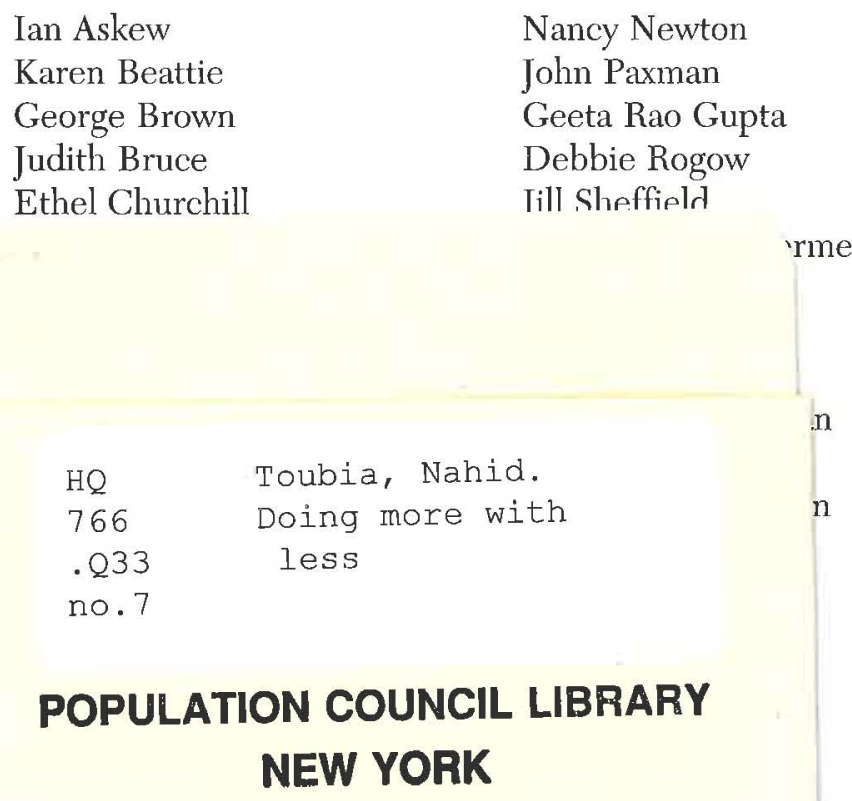

GAYLORD S

We invite your comments and your ideas for projects which might be included in future editions of Quality/Calidad/Qualité. If you would like to receive copies of prior issues or be included on our mailing list, please write to Ann Leonard, Quality/Calidad/Qualité, The Population Council, One Dag Hammarskjold Plaza, New York, N.Y. 10017, U.S.A. 